\title{
OSMANLI COĞRAFYA KAYNAKLARINDA EFLAK-BOĞDAN* (15-17. YÜZYIL)
}

\author{
Ahmet $\ddot{U S T U ̈ N E R} R^{* *}$
}

\begin{abstract}
ÖZ
Balkanlar ve Doğu Avrupa bölgesinde mühim bir konumda yer alan Eflak ve Boğdan, 15. yüzyll sonunda Osmanlı hakimiyetine girmiş̧ir. Gerek siyasi ve stratejik gerekse ekonomik, iaşe ve lojistik açından Osmanlı Devleti için önem taşıyan bölgeye, Osmanlı coğrafya eserlerinde ve kartografyasında erken dönemlerden itibaren yer verilmiştir. Bu anlamda özellikle Özi'den Varna'ya kadar Batı Karadeniz kıyıs1, Tuna Havzası ve Turla (Dinyester) Nehri boyunca mevcudiyeti bulunan yerleşim birimleri 15-17. yüzyılda çizilen Osmanlı haritalarında ve kaleme alınan coğrafya eserlerinde dikkat çeken bölgeler olarak görülür. Bu çalışmada Osmanlı coğrafya yazma eserlerinde Eflak-Boğdan bölgesinin nasıl ve ne derece yer bulduğu incelenirken, bazı noktalarda dönemin Avrupa coğrafya atlaslarıyla da kıyaslamalara gidilmiştir. Yine, Batlamyus'un coğrafya tercümesinden itibaren Piri Reis, Ali Macar Reis, Katib Çelebi, Ebubekir Dımeşki gibi önde gelen Osmanlı coğrafyacılarının eserleri ve bir kısım anonim coğrafya çalışmaları üzerinden değerlendirmeler yapılmaktadır.
\end{abstract}

Anahtar Sözcükler: Eflak, Boğdan, Romanya, Osmanlı Devleti, Osmanlı coğrafyacılı̆̆ı, Osmanlı haritacılığı, Piri Reis, Katib Çelebi

\section{WALLACHIA AND MOLDAVIA IN OTTOMAN GEOGRAPHICAL SOURCES (16-17 ${ }^{\mathrm{TH}}$ CENTURIES)}

\begin{abstract}
Wallachia and Moldavia, which occupied an important position in the Balkans and Eastern European region, came under the Ottoman rule at the end of the 15th century. The region, which was important for the Ottoman Empire in terms of political and strategic as well as economic, subsistence and logistics, was included in the Ottoman cartography and geography books from the early years of the Empire. In this sense, especially important settlements from Ochakov to Varna, the West Black Sea Coast, along the Danube Basin and the Dniester River are seen as remarkable regions in the drawn Ottoman maps and written geographical books in the 15-17th centuries. This article, while examining how and to what extent the Wallachia and Moldavia region had a place in Ottoman geographical manuscripts, at some points, comparisons were made with European geographical atlases of the
\end{abstract}

* Gönderim tarihi: 15.02.2020. Kabul tarihi: 22.04.2020.

** Dr. Öğr. Üyesi, İstanbul Üniversitesi, Türkiyat Araştırmaları Enstitüsü, İSTANBUL. ahmetustuner@gmail.com ORCID:0000-0001-5758-0622 
period. Similarly, in the article, evaluations are made on the books of the leading Ottoman geographers such as Piri Reis, Ali Macar Reis, Katib Çelebi, Ebubekir Dımeşki and some anonymous Ottoman geographical manuscripts.

Keywords: Wallachia, Moldavia, Romania, the Ottoman Empire, Ottoman geography studies, Ottoman cartography, Piri Reis, Katib Çelebi

\section{Giriş}

Tarihsel adlandırma ile Eflak (Wallachia/Valachia/Valakya) bugün Romanya'nın güney kesiminde yer alan bölge olup kuzeyde Karpat Dağları güneyde Tuna (Danube) Nehri ile doğal sınır oluşturan coğrafyayı ifade etmektedir. ${ }^{1}$ Boğdan (Moldaviya-kısmen Besarabya) ise genel itibariyle Eflak'ın kuzey doğusunda yer alan bugünkü Romanya'nın doğu kısmı ile Moldova topraklarının bulunduğu bölgeyi ifade eder.

Hunlar ve Avarlardan itibaren pek çok kez Moldaviya ve Valakya Prenslikleri'nin Türklerle karşılaşması söz konusudur. Osmanlı Devleti döneminde ise Sultan I. Murad'ın (1326-1389) Bulgar Çarı Şişman'a yardımı sebebiyle ilk kez 1368 yılında Eflaklar ile karşılaşılmış, sonrasında devam eden mücadeleler neticesinde Çelebi Mehmed devrinde (1413-1421) Eflak vergiye bağlanmıştır. Bu dönemde Osmanlı Devleti ile Eflak ve Boğdan'nın müşterek sınıra sahip olmalarıyla ilk ilişkileri başlamıştır. ${ }^{2}$ Osmanlı Devleti sonraki süreçte bu bölgede mutlak bir hakimiyet sağlamak için Boğdan'a yönelmiş, ancak bölgenin önemli bir noktası olan Akkerman kuşatılmasına rağmen başarılı olamamıştır. Sonraki süreçte bölgedeki hakimiyet mücadeleleri devam etmiş ve Sultan II. Mehmed döneminde (1451-1481) İstanbul'un fethini müteakip 1455'te Boğdan Voyvodası Petru Aron, yılda 2000 altın haraç vermeyi kabul ederek Osmanlı hakimiyetini tanımış, ancak Boğdan bütünüyle Osmanlı idaresi altında bir eyalet haline getirilememiştir. ${ }^{3}$

Geçen süre zarfında Osmanlı Devleti ile Eflak-Boğdan arasında askeri ve siyasi mücadeleler devam etmiştir. Sultan II. Bayezid'in (1481-1512) 1484 yılında Boğdan üzerine sefer düzenlemesi her iki prensliğin kaderinde de önemli değişime sebep olmuştur. II. Bayezid'in Tuna'nın kuzey kolu üzerinde kurulan ve Boğdan-Lehistan yollarını kontrol eden Kili Kalesi ile Dinyester (Turla)

Kemal Karpat, "Eflak", DIA, C: X, İstanbul 1994, s. 466-469.

2 Mihail Guboğlu, "Osmanlılarla Romen Ülkeleri Arasındaki İlk Devir İlişkileri (1368-1456) Hakkında Belirtmeler ve Doğrultmalar", IX. Türk Tarih Kongresi, Bildiriler, C: II TTK, Ankara 1988, s. 837.

3 İsmail Hakkı Uzunçarşılı, Osmanlı Tarihi, C: II, Ankara 1995, s. 73-80. Mihail Guboğlu, "Fatih'in Stefan cel Mare Üzerine İki Boğdan Seferi 1474-1476", Belleten, C: XLVII, S: 185, Ankara 1983, s. 139-194; Mihail Guboğlu, "Kanuni Sultan Süleyman'ın Boğdan Seferi ve Zaferi”, Belleten, C: L, S: 198, Ankara 1996, s. 728-805. 
Nehri'nin Karadeniz'e döküldüğü haliçte yer alan Akkerman'ı ele geçirmesiyle Eflak-Boğdan' da Osmanlı hakimiyeti kalıcı hale gelmiştir. ${ }^{4}$ Moldaviya bu süreç sonrasında Osmanlı kaynaklarınca ilk müstakil devleti kuran voyvodaya atfen Kara Boğdan ve Boğdan olarak anılagelmiştir. ${ }^{5}$

Bölgede Osmanlı hakimiyeti her ne kadar kalıcı olsa da tam anlamıla sükûnet sağlanamamış, çoğu kez Eflak ve Boğdan voyvodaları askeri ve siyasi mücadelelerle Osmanlı hakimiyetinden çıkma teşebbüslerinde bulunmuşlardır. $\mathrm{Bu}$ bölgedeki Osmanlı hakimiyeti diğer eyaletlere nazaran daha farklı bir statü seyretmiştir. Yerel idareciler atanması dışında voyvodalıkların idari yapılarına müdahale edilmemiştir. Kanuni Sultan Süleyman'ın (1520-1566) 1526 y1lında Macaristan topraklarını fethetmesiyle Eflak üzerindeki Macar nüfuzu sona ermiş, ardından Boğdan Voyvodası Petru Rareş (1527-1538, 1541-1546) başkaldırıda bulunmuş, Erdel'i işgal edip ödemesi gereken vergiyi vermemiştir. Bunun üzerine Kanuni Sultan Süleyman Boğdan Seferi'ne çıkmış, sükûnet sağlanmışsa da sonrasında yine karmaşa baş göstermiştir. Osmanlı hakimiyetinden çıkmak amacıyla pek çok yola başvuran voyvodalar bazen komşu devletlerle iş birliğine giderken bazen de ittifak kurma teşebbüslerinde bulunmuşlardır. Eflak Prensi Mihai Viteazul (1593-1601) 1599'da önce Erdel'e daha sonra Hotin'e kadar gelerek Boğdan'da hakimiyet kurmuş, 1600 yılında kısa müddet de olsa üç prensliği tek çatı altında toplamayı başarmıştır. 1601'de Mihai'nin ölümü ile bu ittifak tekrar parçalanmıştır. ${ }^{6}$

Stratejik öneme sahip olan bölge 17. yüzyılda Osmanlı-Leh mücadelelerine sahne olmuştur. Lehistan Kralı III. Zygmunt Waza'nın (1587-1632) Boğdan'a saldırması sonucunda iki taraf Cecora'da karşı karşıya gelmiş ve mücadele Osmanlı kuvvetlerinin galibiyetiyle sonuçlanmıştır. Ardından Sultan II. Osman 1621'de Hotin Seferi'ne çıkmış, ancak iki tarafın mutlak galibiyeti mümkün olmamıştır. 1621'de yapılan Hotin Antlaşması'yla Dinyester Nehri iki ülke arasında hudut kabul edilmiştir. ${ }^{7} 1657$ 'de ise Erdel Prensi II. George Rakoçi (II. Rákóczi György, 1648-1660)'nin isyanı ve akabinde Lehistan'a saldırmas1 bölgede yeni bir karmaşayı doğurmuştur. Veziriazam Melek Mehmed Paşa'nın müdahalesiyle durum sabitlenmiştir. Yine Osmanlı Devleti'nin 1672 Kamaniçe Seferi bölgede dengeleri değiştirmiş, Kamaniçe'nin Lehistan'dan alınması EflakBoğdan'ın önemini artırmıştır. Hotin ise bir süreliğine Boğdan'a bağlanmış, 1711 'den sonra Boğdan Voyvodalığı'ndan alınarak doğrudan merkeze bağlı sancak haline getirilmiştir. ${ }^{8}$ Voyvoda Konstantin Kantemir'in (1685-1693) oğlu Dimitri Kantemir'in Rusya ile işbirliğine girişi ve yaşanan Prut Savaşı'ndan (1711) sonra Eflak ve Boğdan Voyvodaları yerli prenslerden değil, merkezden

\footnotetext{
Kemal Karpat, "Bucak", DIA, C: VI, İstanbul 1992, s. 341-343.

Abdülkadir Özcan, “Boğdan”, DİA, C: VI, İstanbul 1992, s. 269-271.

Karpat, a.g.m., s. 468.

Dariusz Kołodziejczyk, "Hotin”, DIA, C: 18, İstanbul 1998, s. 253-254.

Kołodziejczyk, a.g.m., s. 254.
} 
atanacak Rum beylerinden tayin edilmeye başlanmıştır. "Fenerli Beyler" dönemi denen bu süreç 1821 'e dek sürmüştür. ${ }^{10}$ Rusya, 1774 Küçük Kaynarca Antlaşması ile Eflak ve Boğdan Voyvodalıkları'na karışma hakkı elde etmiş, 1787-1792 Osmanlı-Rus ve Avusturya Savaşı, Boğdan ile Rusya'yı sınır hale getirmiştir. 1812 Bükreş Antlaşması, 1827-1829 Osmanlı-Rus Savaşı ile Osmanlı Devleti'ne olan bağlılığı zayıflayan voyvodalıklar, 1856 Paris Antlaşması'ndan sonra bir süre Birleşik Prenslikler olarak varlığını sürdürmüştür. 1877-1878 Osmanlı-Rus Savaşı sonunda Romanya adıyla bağımsızlığını ilan etmiştir. ${ }^{11}$ Bölgedeki Osmanlı hakimiyeti Ayastefanos ve Berlin Antlaşmaları'nda Romanya'nın tanınmasıyla son bulmuştur. ${ }^{12}$

Avusturya, Lehistan ve Rusya bağlamında siyasi önemi yanında, Balkanların ve Karadeniz ticaretinin önemli merkezi olması, aynı zamanda buradaki nehirlerin bir kısmında taşımacılık yapılması da bölgeyi Osmanlılar açısından önemli kılmaktadır. Aynı zamanda Osmanlı Devleti'nin iaşesinin sağlanmasında bölge kıymet taşımaktaydı. ${ }^{13}$ Bu anlamda Tuna, Dinyester (Turla), Prut Nehirleri bölgenin önemli noktalarıdır. Yine Osmanlı Devleti’nin Avrupa ile yürüttüğü dış politikalarda ve Avrupa'dan haber alma kanallarından biri olarak da Eflak ve Boğdan'ın stratejik ehemmiyeti söz konusudur. ${ }^{14}$ Diğer yandan Tatarların, Gagavuzların ve Nogayların yerleşim noktası olması dolayısıyla askeri-stratejik önemi bulunmaktadır.

\section{Osmanlı Coğrafya Eserlerinde Eflak-Boğdan}

Avusturya-Macaristan, Lehistan ve Rusya'ya açısından önem arzeden geniş bir coğrafya olarak Eflak ve Boğdan (Harita 1), siyasi ve ticari faaliyetlerin birleştiği konumda olması bakımından Osmanlılar açısından büyük anlam taşır. $^{15}$ Nitekim bu önem, dönemin yazılı kaynaklarının yanı sıra coğrafya eserlerine ve birtakım haritalara da yansımıştır. Bu noktada çalışma, Eflak ve

9 Uzunçarşı1lı, a.g.e., C: IV-II, s. 86-103; İsmail Hakkı Uzunçarşılı, “On Sekizinci Asırda Buğdan'a Voyvoda Tayini”, Tarih Semineri Dergisi, C: I, Ankara 1937, s. 32-37.

10 Fenerli Beyler dönemi üzerine değerlendirmeler için bkz. Zeynep Sözen, Fenerli Beyler, 110 Yllın Öyküsü (1711-1821), İstanbul 2000, s. 13-25; Christine M. Philliou, Biography of an Empire: Governing Ottomans in an Age of Revolution, Berkeley, Los Angles, London 2011.

11 Karpat, a.g.m., s. 467, 469.

12 Özcan, a.g.m., s. 271.

13 Mihai Maxim, "Tuna-i'Amire: L'organisation financière et militaire du danube Ottoman aux XVIe et XVIIe siècles à la lumière de documents Ottomans inédits", Romano-Turcica, I içinde, İstanbul 2003, s. 75-82; Mihai Maxim, "Moldova", DİA, C: 30, İstanbul 2005, s. 237.

14 Bkz. Mehmet Alaaddin Yalçınkaya, "The Role of The Principalities of Wallachia and Moldavia on Ottoman Foreign Policy at the time of Selim III (1789-1807)", Codrul Cosminului, C: XXIV, S: 1, Suceava 2018, s. 179-204; Cafer Çiftçi, "Bâb-1 Âlî’nin Avrupa'ya Çevrilmiş İki Gözü: Eflak ve Boğdan'da Fenerli Voyvodalar (1711-1821)”, Uluslararası İlişkiler, C: 7, S: 26, İstanbul 2010, s. 27-48.

15 Osmanlılar döneminde Eflak ve Boğdan'ı değerlendiren bir çalışma olarak bkz. Mehmed Şevki, "Memleketeyn-i Müctemiateyn: Eflak-Boğdan”, Mecmua-i Fünun, C: IV, S: 35, İstanbul 1283, s. 56-69. 
Boğdan havalisinin Osmanlı harita ve eserlerine ne şekilde yansıdığı noktasına odaklanmaktadır. 15-17. yüzyıllarda kaleme alınan Claudius Ptolemaios (Batlamyus el Kaluzi, 100-?), Atlas Minor (Gerardus Mercator, 1512-1594) ve Atlas Mayor (Joan Blaeu, 1596-1673) tercümeleri; Piri Reis (1470-1553), Ali Macar Reis (16.yy), Katib Çelebi (1609-1657), Ebubekir Behrâm ed-Dımeşki (?-1691) ve Evliya Çelebi gibi coğrafyacıların çizimleri ve anlatımları; Atlas-ı Hümayun (16.yy), Walters Deniz Atlası (16.yy) gibi eserler ile arşivlerde bulunan müstakil Eflak-Boğdan haritaları çalışmanın temel kaynaklarıdır.

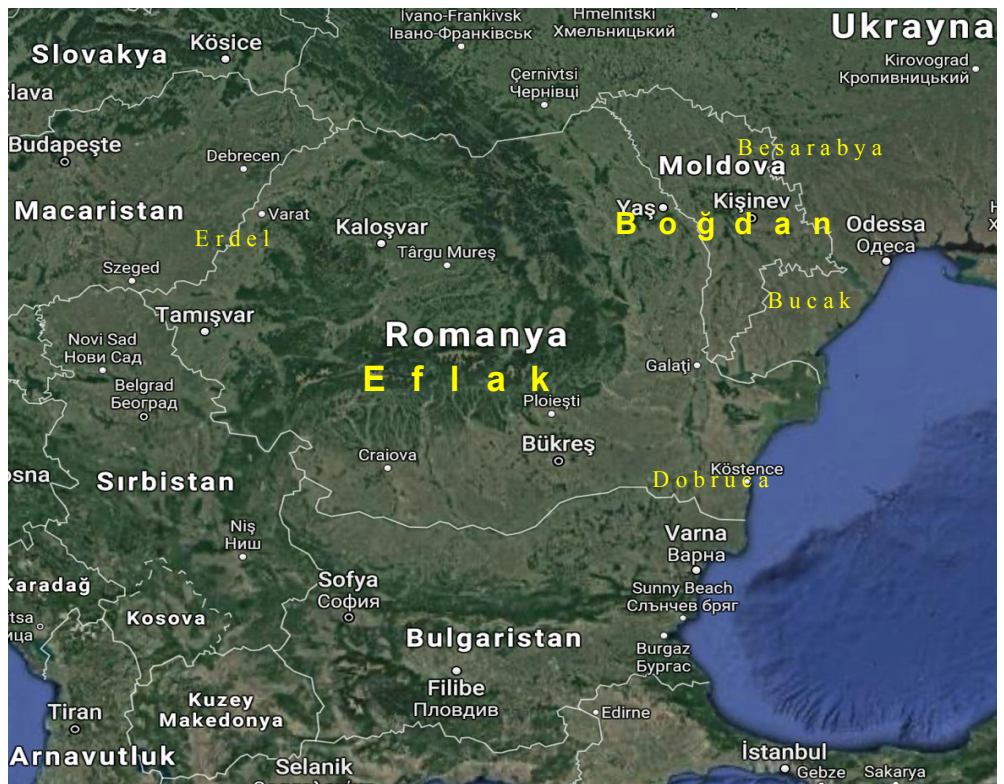

Harita-1: Güncel Harita Üzerinde Eflak-Boğdan’ın Konumu (๔ Ahmet Üstüner)

Eflak-Boğdan'ın stratejik konumu, bölgede yaşanan siyasi ve askeri hadiseler bölgenin plan ve haritalarının çizilmesini gerektirmiş; özellikle 17. yüzyılda Lehistan ve Rusya ile yaşanan askeri hadiseler sınırların yeniden tespiti ve yeni sınırların gösterilmesi meselesi de aynı şekilde haritaların gerekliliğini ortaya çıkarmıştır. Bunun yanında bölgenin detaylı harita ve planlarının devletin stratejik siyaseti açısından elde bulunması lüzumu da yine çeşitli Osmanlı haritalarının çizilmesinde etkili olmuştur. Ayrı bir perspektif olarak 16. ve 17. yüzyıl Osmanlı coğrafyacıları ve bilim adamları tarafindan bölgeyi tanıma gayretleri sebebiyle Eflak-Boğdan'ın detaylı haritaları çizilmiş ve coğrafi açıdan tasvir edilmiştir. Gerek dönemin yazma eserlerinde gerekse perakende evrak olarak bu çizimlerin bir kısmı günümüze ulaşmıştır. Yazma eserlerde daha ziyade bölgeyi tanıtan haritaların çizildiği söylenebilir. $\mathrm{Bu}$ çizimler genel itibariyle Eflak-Boğdan’ın coğrafi olarak gösterilmesi şeklindedir. 17. yüzyıl sonu ve 18. yüzyılda ise daha ziyade askeri amaçlı olarak bölgeye mahsus detaylı harita ve plan çizilmeye başlanacaktır. Coğrafya biliminde Avrupa'da 
görülen gelişmeler zaman içerisinde bölgenin daha detaylı haritalandırılmasını gerektirmiş, bu süreç benzer şekilde Osmanlı kartografyasına da yansımıştır.

Eflak ve Boğdan, Karadeniz'in batı kıyısında stratejik öneme sahip konumuyla ve kıyı şeridi limanları sebebiyle pek çok portolanda ${ }^{16}$ gösterilmiştir. Osmanlılar ile muhtemel bağlantısı olan Süleyman Et-Tanci'nin (Tancalı Ahmed) 1413 tarihli portolanı bu anlamda bölgeye yer veren ilk çizimlerdendir. ${ }^{17}$ Yine Fatih Sultan Mehmed'in emriyle Batlamyus Coğrafyası'nın Amyrutzes tarafindan Kitâbü'l-Coğrâfya fi'l-ma 'mûre mine'l-arz ismiyle Grekçeden Arapçaya tercüme edilmiş nüshasında, Grekçe metne muvafik olarak aktarılan AsyaAvrupa haritalarında Eflak-Boğdan coğrafyasının belirtildiği görülür. ${ }^{18}$ Batlamyus Tercümesi'nde yer alan her iki haritada da özellikle Tuna Deltası'nın ayrıntılı olarak gösterilmesi, nehir, yerleşim ve dağların belirtilmesi dikkat çeken hususlardır (Harita 2-3). Harita, erken dönemlere ait olmasına rağmen bölge ile ilgili dikkat çekici ayrıntılar barındıran çizimler, kartografik bilgi, izdüşüm teknikleri ve enlem-boylam değerleri taşıması açısından da önem taşır. Batlamyus Sistemi'ne istinaden $14-15^{\circ}$ derece enlem ve $47-58^{\circ}$ boylamları arasında gösterilen haritada El-Bahri'l-Pontı ve'l-Esved, Vilâyet-i Eflac, Valzakiya, Vilâyet-i Üngürüs, Vilâyet-i Bulgar ve Cebel-i Karpat gibi isimlendirmeler görülmektedir. ${ }^{19}$ Ayrıca harita-3'te daha detaylı olarak yerleşim yerleri ve Tuna üzerindeki kaleler gösterilmektedir. Bu bağlamda, Tuna Nehri'nin kolları ile birlikte belirgin şekilde gösterildiği haritada isimlendirmede Grekçenin yanı sıra Türkçe ve Arapça kullanımlar da dikkat çeker. Yukarıdan aşağıya (günümüz değerleriyle güneyden kuzeye) doğru Karadeniz kıyısı isimlendirmeleri takribi olarak şu şekildedir: ${ }^{20}$ Cezîre-i Akillisu'l-Beyzâ (Achillis insula), Fadistenis? (Borysthenis insula), Nehr-i Aksakes (Axiacus fl.), Nehr-i Troli (Tyras fl.), Fisk (Tyras), Edbis?, Fagol, Fem-i şimâlî, Fem-i Kadib?, Anarkon, Fem-i Kudsî, Aks1 Piteron (Pterum Pro), Istropolis, Tom, Klats/Kalats, Diyonisopolis, Odissus, Aksi Tristis (Tristris Pro), Nehr-i Pans, Mesemor... (Mesemoria), Apoloniye. Kıyı şeridinin dışında kalan iç kısımlarda ise yine kuzeyden güneye takribi

16 Portolan, kıyı ve limanlara dair bilgi veren deniz haritalarıdır.

17 Topkapı Sarayı Müzesi Kütüphanesi, (TSMK), Hazine: 1823, Fikret Sarıcaoğlu, "Harita", DIA, C: XVI., İstanbul 1997, s. 210. Ayrica bkz. Piri Reis'ten Önce ve Sonra: Topkapr Sarayı'nda Haritalar, ed. Ahmet Menteş vd., İstanbul 2013, s. 40-41.

18 Batlamyus ve eseri ile ilgili olarak bkz. Cengiz Aydın-Gülseren Aydın, "Batlamyus", DİA, C: V, İstanbul 1992, s. 196-199. Batlamyus Coğrafyası için bkz. Edward Luther Stevenson, Claudius Ptolemy The Geography, Dover Publications, New York 1991; Ayrica tercümenin başka bir nüshası için bkz. Süleymaniye Yazma Eserler Kütüphanesi, Ayasofya: 2596. Eserin Latince nüshası için bkz. La Cosmographie de Claude Ptolemée, 1411-1424. https://commons.wikimedia.org/w/index.php?title=File:La_Cosmographie_de_Claude_Ptole mée.pdf\&page $=4$ Eserin Grekçe tıpkıbasımı için bkz. Klaudios Ptolemaios, Coğrafya El Kitabl, İstanbul 2017.

19 Haritalardaki yer adları kaynaklarda geçtiği üzere isimlendirilmiş olması nedeniyle aynı yer adlarının farklı yazımları görülebilir. Transkripsiyonda Osmanlıca esere mutabık kalınmıştır.

20 Yer adları Arapça seslerin karşılı̆̆ 
isimlendirme şöyledir: Kresezk, Atiz, Truvad, Arkovzar, Terzbav, Terfil, Angusta, Nehr-i Arasus, Baloda, Pirorze, Mesâkin-i Kafkavansis, Zuszane, Dinogadiye, Mesâkin-i Traktis, Mesâkin-i Targalozit, Tersmis, Nozene, Karson, Noane, Sitavest, Aksipolis, Sekzeve, Tirmarsk (Tirista), Verstron, Mesâkin-i Karitnisis, Mesâkin-i Bafis, Tiyas, Netnaze...
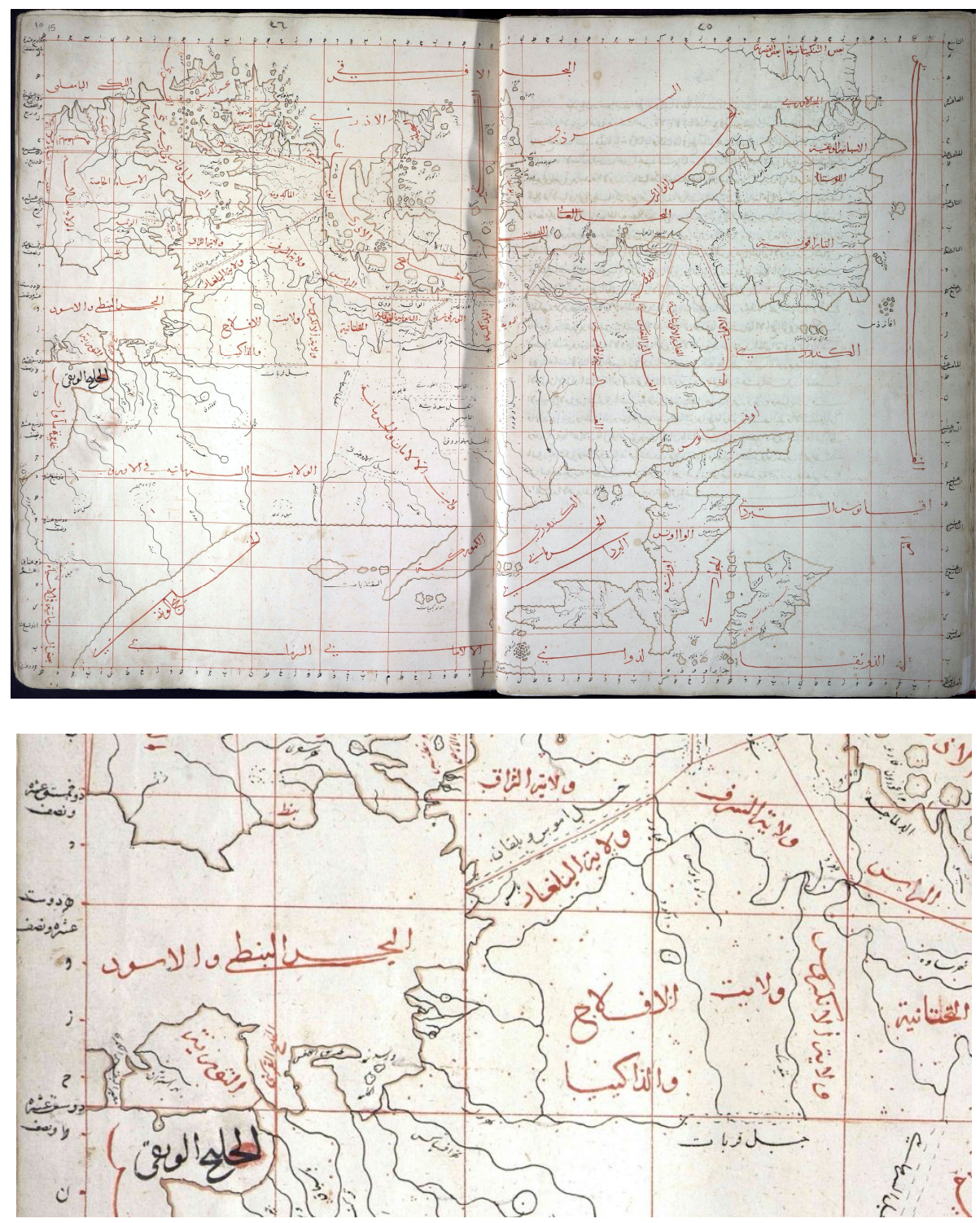

Harita-2/1, 2/2: Avrupa Haritası, Batlamyus, Kitâbü'l-Coğrâfya fi'l-ma 'mûre mine'l-arz, Süleymaniye Yazma Eserler Kütüphanesi, Ayasofya: 2610. 

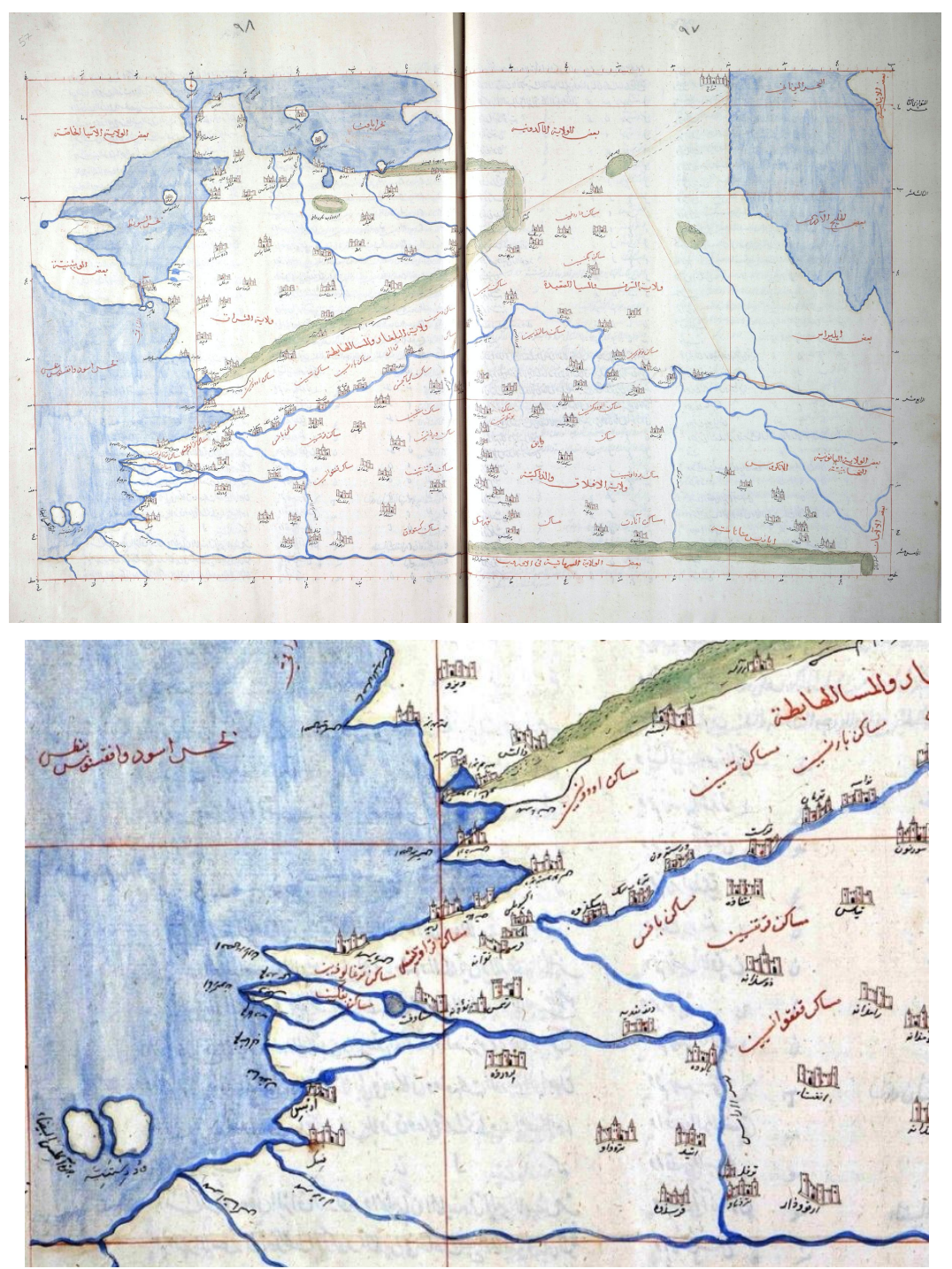

Harita-3/1, 3/2: Doğu Avrupa, Batlamyus, Kitâbü'l-Coğrâfya fi 'l-ma 'mûre mine'larz, Süleymaniye Yazma Eserler Kütüphanesi, Ayasofya: 2610.

Yine 15. yüzyılın önemli çizimlerinden Tunuslu İbrahim El-Mürsi tarafindan Tunus'ta çizildiği belirtilen 1461 tarihli haritada Eflak-Boğdan bölgesinin kıyı şeridi itibariyle yer aldığı görülür. ${ }^{21}$ Bölgeyi gösteren bir diğer portolan ElHac Ebu'l-Hasan tarafindan çizilmiştir. Kanuni Sultan Süleyman dönemine

21 Svat Soucek, Piri Reis ve Kolomb Sonrası Türk Haritacıllğgl, İstanbul 2013, s. 38; Murat Tanrıkulu, "Portolan Haritaların Kaynağı, Genel Özellikleri ve Etkileri”, Harita Dergisi, S: 157, Ankara 2017, s. 34. 
atfedilen haritada Eflak-Boğdan coğrafyası, Tuna havzası ve Karadeniz’in Bat1 şeridi kale ve yerleşim yerleriyle birlikte detaylı olarak gösterilmektedir. ${ }^{22}$ Benzer şekilde Kanuni Sultan Süleyman döneminde yapıldığı düşünülen müellifi meçhul haritalardan, Avrupa'yı gösteren bir haritada da muhtasar olarak Eflak-Boğdan bölgesi gösterilmiş olmalıdır. ${ }^{23}$

16. yüzyılda bölgedeki Osmanlı hakimiyetinin sağlamlaşması ve Osmanlı kartografyasında görülen ilerlemeye mukabil, Eflak-Boğdan'a dair harita ve anlatımların yaygınlaştığı görülür. 16. yüzyılın ilk yarısında (15211528) Piri Reis'in sadece kıyı şeridinde limanları, liman kentlerini ve rüzgâr yönlerini gösteren rüzgâr gülü ekseninde çizilmiş portolan tarzı haritalarında Azak Denizi ile birlikte Karadeniz ve Doğu Avrupa coğrafyasının genel hatlarıyla belirtildiği görülür (Harita 4-5). Haritalardan her ikisinde de Tuna Nehri kolları ve deltası ile birlikte belirgin bir şekilde gösterilmekte, ayrıca ikinci (Harita 4) haritada bütünüyle Karadeniz kıyı şeridi ve önemli liman şehirleri kaydedilmektedir.

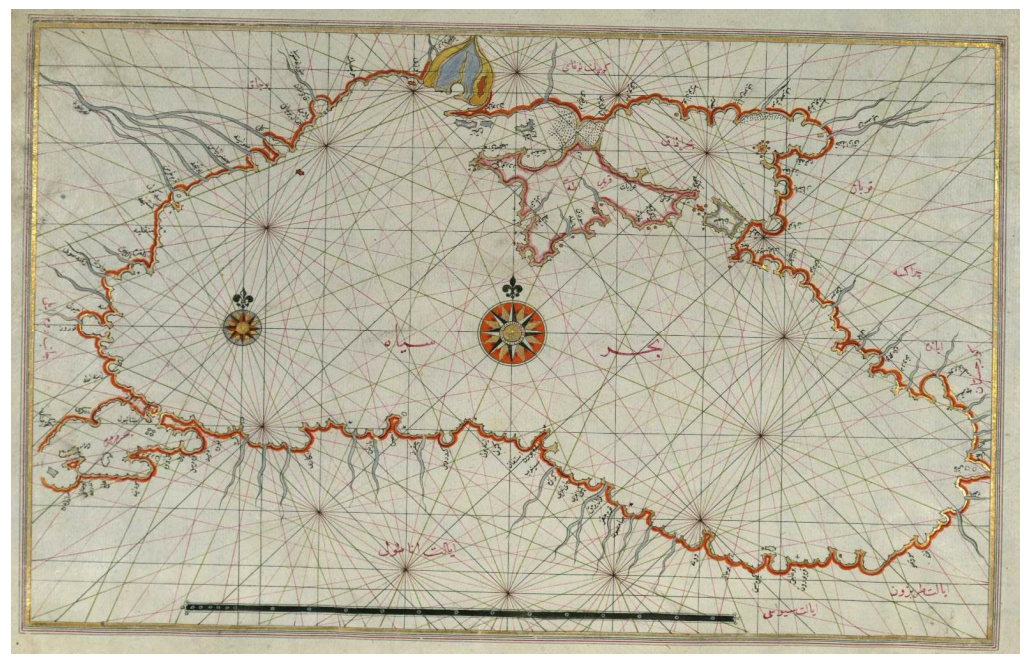

Harita-4/1: Karadeniz Haritası, Piri Reis, Kitâb-ı Bahriyye, Walters Koleksiyonu

Buna göre Batı Karadeniz sahil şeridinde Dinyeper (Özi) Deltası'ndan itibaren Hocabey, Turla (Dinyester) Suyı, Akkerman, Kili, Soline, Potince, Hızır

22 TSMK, Hazine: 1822; İbrahim Hakkı Konyalı, Topkapı Sarayında Deri Üzerine Yapılmış Eski Haritalar, İstanbul 1936; Fikret Sarıcaoğlu, "Piri Reis'in Dünya Haritaları ve Kitab-1 Bahriyye'si", Piri Reis'ten Önce ve Sonra Topkapı Sarayl'nda Haritalar içinde, İstanbul 2013 s. 50; Tanrikulu, a.g.m., s. 34; Ayrica bkz. Piri Reis'ten Önce ve Sonra: Topkapı Sarayı'nda Haritalar, s. 92-93.

23 Topkapı Sarayı Müzesi Kütüphanesi'nde vaktiyle 67 numara ile kayıtlı olan haritaya ulaşılamamıştır. (Müzede daha sonradan yapılan tasniflendirmelerden ve numaralandırmalardan dolayı künyeler değişmiştir ve günümüzde bazı haritalar ise mevcut değildir.) Ayrıntılı bilgi için bkz. Abdurrahman Aygün, "Topkapı Sarayı Müzesindeki Coğrafi Eserler ve Haritalar", Haritalar Mecmuası, C: IV/13, İstanbul 1933, s. 113. 
İlyas (Sfantul George), Kara Harman, Köstence ve Varna'dan İstanbul'a kadar Bucak ve Dobruca kısmen ayrıntıya girilmeden gösterilmektedir. ${ }^{24}$

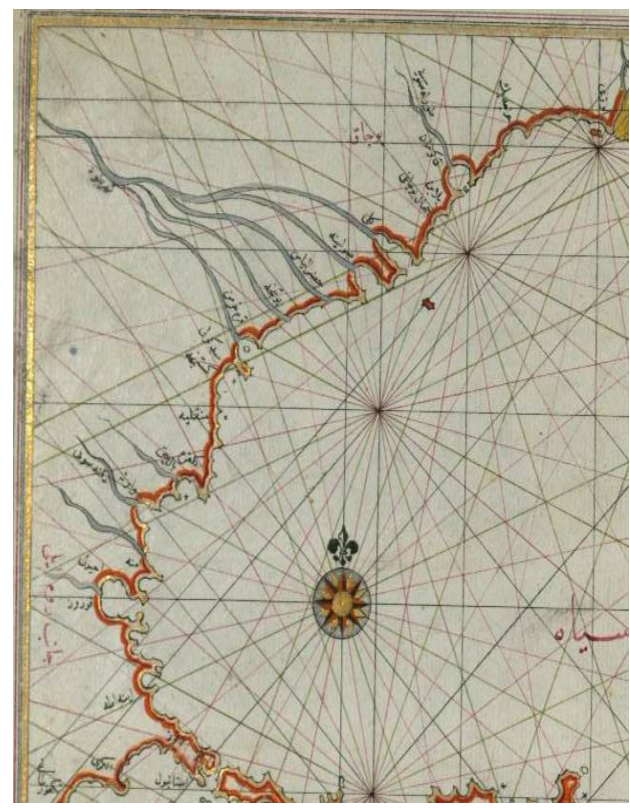

Harita-4/2: Karadeniz Haritas1, Piri Reis, Kitâb-ı Bahriyye, Walters Koleksiyonu

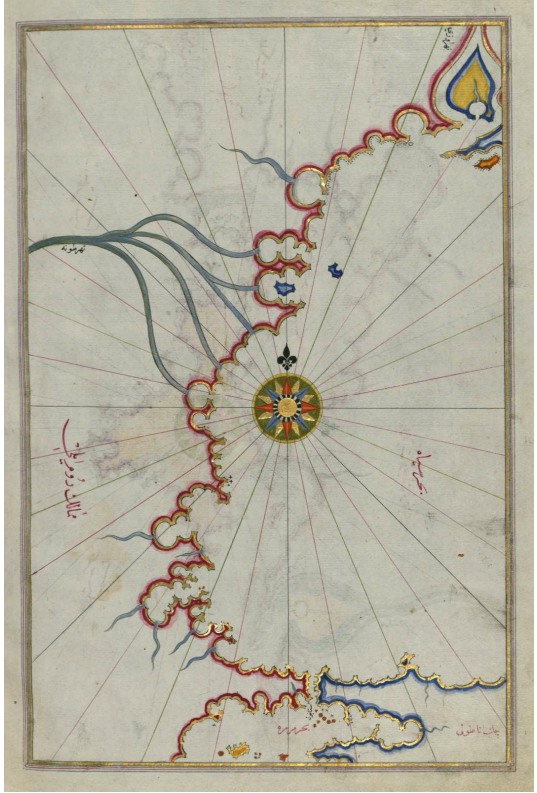

Harita-5: Tuna Deltas1, Piri Reis, Kitâb-ı Bahriyye, Walters Koleksiyonu

Piri Reis haritalarından yaklaşık 40 yıl sonra yine portolan tarzında çizimlerle, birbiriyle pek çok açıdan benzerlik gösteren Ali Macar Reis Atlası ${ }^{25}$,

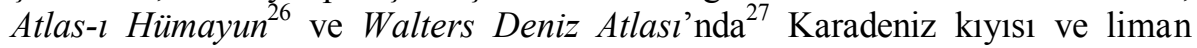

24 Piri Reis'in Kitab-1 Bahriyye'sinin farklı versiyonu olarak adlandırılan Seyyid Nuh'un Deniz Kitabı (Kitâbu bahri'l-esved ve'l-ebyad)'nda benzer şekilde Karadeniz Haritası bulunmaktadır. Tek nüshası bulunan eser Bologna'dadır. (Bibliotheka Universiteria Ms. 3609). Ayrıntılar için bkz. Hans J. Kissling, Der See-Atlas des Sejjid Nûh, München 1966; Franz Babinger, "Seyyid Nuh and His Turkish Sailing Handbook." Imago Mundi C: 12, London 1955, s. $180-82$.

25 Eser hakkında ayrıntılar için bkz. Fevzi Kurtoğlu, Türk Süel Alanında Harita ve Kroniklere Verilen Değer ve Ali Macar Reis Atlası, İstanbul 1935; Kemal Özdemir, Osmanl Deniz Haritalart: Ali Macar Reis Atlast, İstanbul 1992.

26 Atlas hakkında değerlendirmeler için ayrıca bkz. Thomas Goodrich, "Atlas-1 hümayun: A Sixteenth-century Ottoman Maritime Atlas Discovered in 1984," Archivum Ottomanicum, C: 10, Budapeşte 1985, s. 83-101.

27 Atlas hakkında değerlendirmeler için ayrıca bkz. Thomas Goodrich, "The Earliest Ottoman Maritime Atlas- The Walters Deniz Atlası" Archivum Ottomanicum, C: 11, Budapeşte 1986, s. 25-50 Ayrıca bkz. Günsel Renda, "Resimli Haritalar ve Topkapı Sarayı Koleksiyonu", 
kentlerine yer verilmiş, Karadeniz'in batı kıyıları ve Tuna Deltası ayrıntıya girilmeden gösterilmiştir (Harita 6, 7, 8). Söz konusu bu atlaslardan ilkinin Macar asıllı levent reisi olan Ali Macar Reis tarafından çizildiği bilinmektedir. Diğer iki atlasın ise Osmanlı saray nakkaşhanesinden çıktığı bilinmektedir, ancak haritacı/müelliflerine (musannif) dair bilgi henüz bulunamamıştır. Her üç haritada da bütünüyle Azak ve Karadeniz kıyı yerleşimi kaydedilmiştir. Haritada Özi'den itibaren kuzeyden güneye doğru Varna'ya kadar şu yerleşimler belirtilmiştir: ${ }^{28}$ Özi, Zanbak İlimanı, Hocabeğ İlimanı, Akkerman, Akkerman Boğazı, Turla Nehri, Kili, Kili Boğazı, Yılan Adası, Soline Boğazı, Hızır İlyas Boğazı, Kara Harman, Kara Harman Boğaz1, Köstence, Kuru Bangalya, Sulı Bangalya, Şabla Burnı, Kelugra Bu[r]nı, Balçık, Varna. Yine Tuna Deltası'nda bulunan yerleşimler ve kaleler minyatürize edilerek doğudan batıya doğru Kili, Kara Harman, Beşkavak, İbrail, Harşova, Evs, Moldarya, Silistre, Tutrakan, Uruscuk, Yergöği, Kula, Niğbolı, Rahve, Vidin, Feth, Surkapu, Horşova, (Orşova) şeklinde yaklaşık $650 \mathrm{kmlik}$ Tuna boyu isimlendirilmiştir. Ayrıca Tuna Nehri her üç haritada da gösterilmişken, Bucak ve Dobruca haricinde EflakBoğdan'ın iç kesimlerine yer verilmesi bakımından Walters Koleksiyonu'nda bulunan harita ön plana çıkar. Bu harita rüzgâr gülleri, dăg ve yerleşim yerleri ve Tuna üzerinde bulunan kalelerin sanatsal olarak resmedilmiş olması ile de dikkat çekmektedir. Tuna boyunca yer alan kalelerin resmedilmiş olması, Varna Körfezi’nde bulunan Varna Gölü olarak bilinen haliç ile birlikte Varna Şehri’nin minyatürize edilmiş olması bakımlarından harita önemlidir. Yine kuzeyde takribi olarak gösterilen Dinyester Nehri (Turla Suyı) ile birlikte Hotin Kalesi ve Kamaniçe, bugün Ukrayna'da yer alan bölge de gösterilmiş olmalıdır.

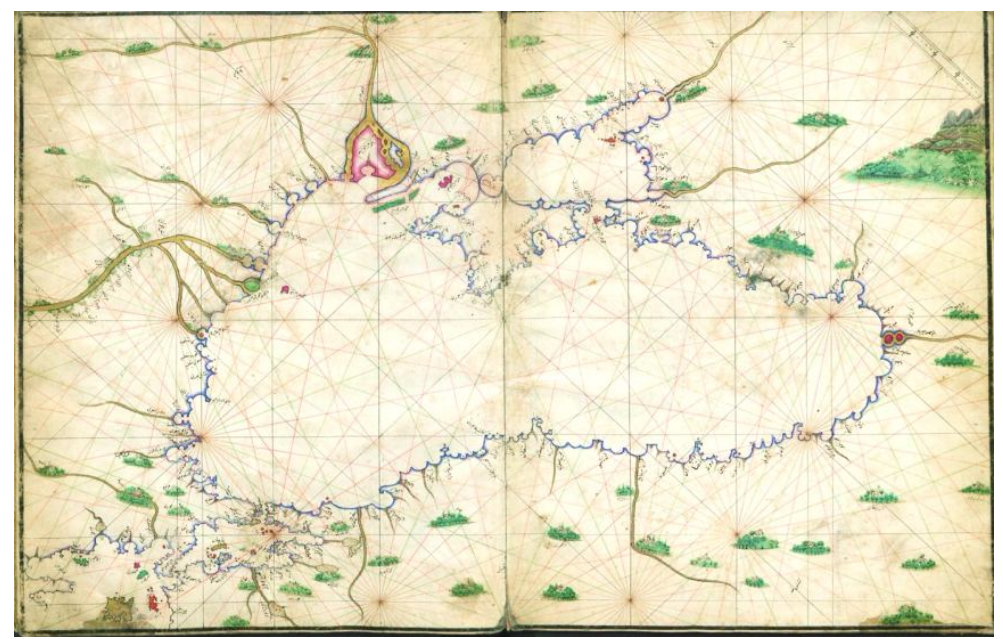

Harita-6 Karadeniz Haritası, Ali Macar Reis, Ali Macar Reis Atlası, TSMK, Hazine: 644

Piri Reis'ten Önce ve Sonra: Topkapı Sarayı'nda Haritalar içinde, ed. Ahmet Menteş vd., İstanbul 2013, s. 43.

28 Burada yer isimlerinin okunmasında Ali Macar Reis Atlası referans alınmıştır. 


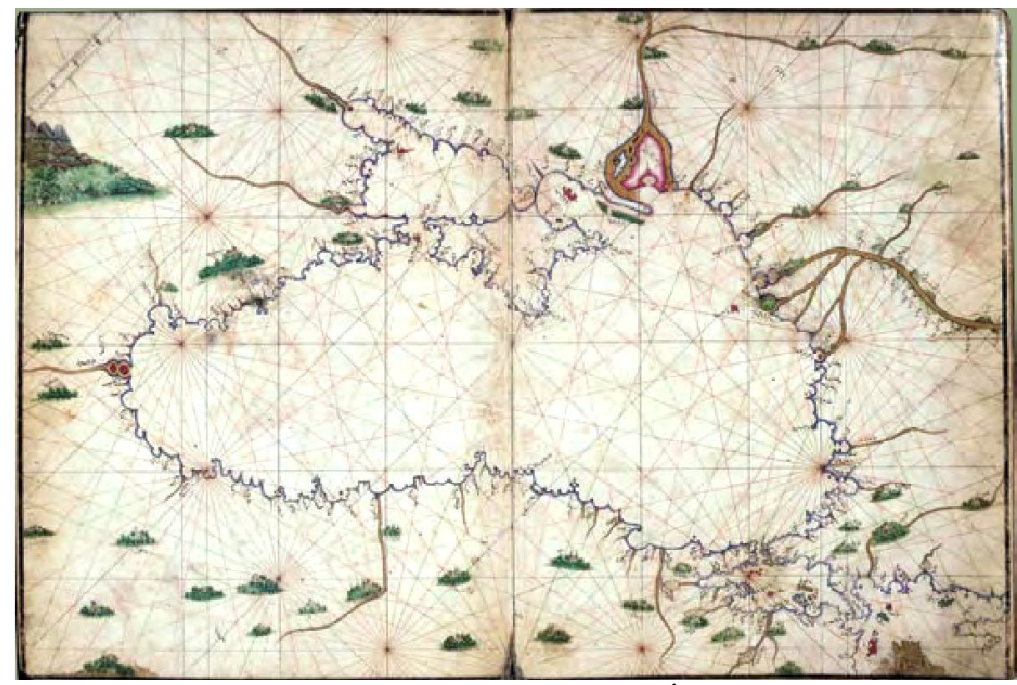

Harita-7: Karadeniz Haritası, Atlas-ı Hümâyûn, İstanbul Arkeoloji Müzesi Kütüphanesi: 1621

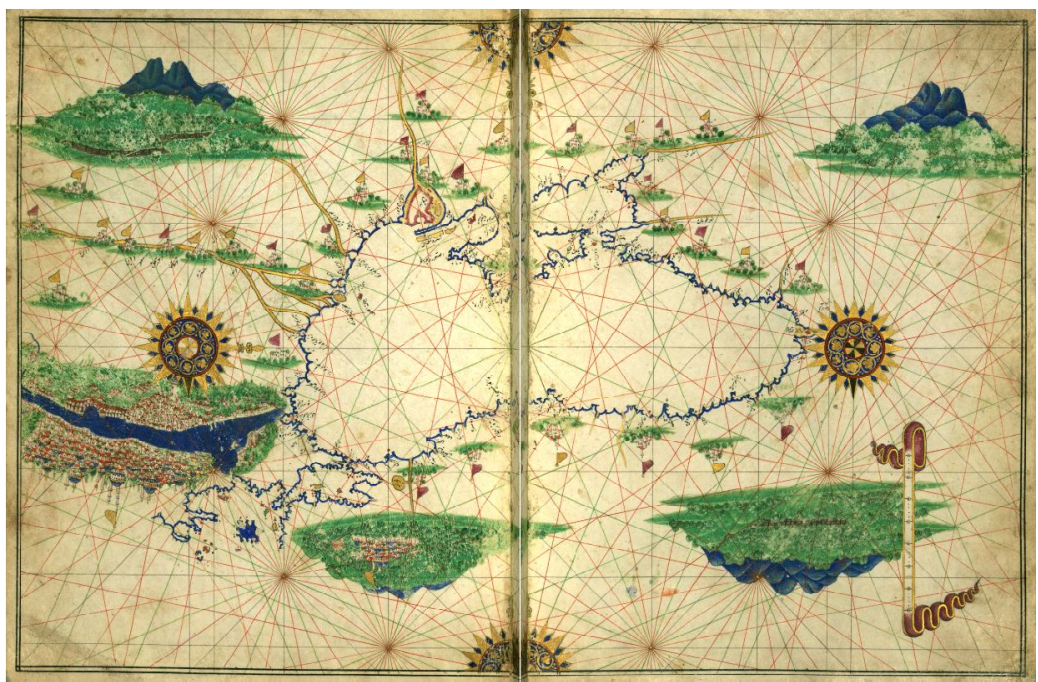

Harita-8: Karadeniz Haritası, Walter Deniz Atlası, Walter Koleksiyonu, Baltimore

Yukarıda gösterilen bu haritaların kaynağına dair henüz detaylı bir çalışma yapılmamışsa da isimlendirmelerde aynı yüzyılda çizilmiş Latince haritalarla Soline, Bangalya gibi isimler açısından benzerlikler dikkat çeker. ${ }^{29}$ $\mathrm{Bu}$ noktada yerel isimlerle birlikte sonradan Türkçeleştirilmiş isimlerin bulunduğunu da belirtmek gerekir.

29 Bkz. Gerardus Mercator, Atlas Sive Cosmographicae Meditationes de Fabrica Mundi et Fabricati Fcigura, Amsterdam 1595, s. 267. 
16. yüzyıl kartografyacılığının genel karakteristiğine uygun olan bu haritalar portolan tarzında olmakla birlikte izdüşüm ve konumlandırma doğruluğu ön planda tutulmadan rüzgâr gülü eksenli olarak çizilmiştir. Kısmen de olsa haritalarda minyatürel çizimler ve birkaç fiziki işaretlendirme dışında ayrıntı da görülmez. Konum doğruluğu kaygısı olmadan yerleşim yerleri takribi gösterilmiştir. Yine 16. yüzyıl, haritacılığın sonraki dönemlere nazaran çok fazla gelişme göstermediği bir dönem olması nedeniyle teknik yaklaşım, derece ve ölçü kavramlarına rastlanmaz. Henüz Osmanlı haritalarında ölçek, izdüşüm, projeksiyon gibi kavramların gündemde olmadığı bu dönemde çizilmiş haritalarda, teknik kaygılardan ziyade pratik kullanılabilirlikle birlikte sanatsal yaklaşım dikkat çeker. Diğer taraftan Eflak-Boğdan'da hakimiyetin tam anlamıyla tesisi nedeniyle siyasi ve askeri ilişkiler ve bölgeden gelen iaşenin önemine bağlı olarak ortaya çıkan deniz ticareti dolayısıyla yukarıda bahsi geçen kıyı şehirleri ve özellikle Tuna kıyı yerleşim ve limanlarına önem verilmiş olsa da bu dönem haritalarının özel bir amaca hizmet ettiğini söylemek güçtür. Bunlar daha ziyade genel haritalardır.

Osmanlı coğrafya kaynaklarında Katib Çelebi'ye kadar Avrupa coğrafyası hakkında bilgiler oldukça sınırlıdır. Evzâhü'l Mesâlik, Menâzıru'l Avâlim gibi klasik dönem tarih-coğrafya eserlerinde bulunan bilgiler Tuna ve Özi Nehirleri hakkında sınırlı anlatımın ötesine geçmez. Evzâhü'l Mesâlik'in nüshalarından İsmihan Sultan Koleksiyonu'nda bulunan ve bilinen eski dünyayı gösteren haritasında da Tuna Nehri'nin belirtilerek isimlendirilmiş olması bu açıdan anlamlıdır. ${ }^{30} 1569$ ve 1572 yıllarında Arapça ve Türkçe olarak iki kez kaleme alınmış olan eserde Nehr-i Tuna ve Nehr-i Özi başlıkları ile nehirlerin menbaından denize döküldügü yere kadar özet halinde bilgiler verilir. Bu minvalde Tisa Nehri, Zemen Ovası, Sakçı (İsakçı), Akkerman gibi malum yerleşimler sadece ismen zikredilmekle yetinilir. ${ }^{31}$

Evzâhü'l Mesâlik'te bulunan Tuna ve Özi Nehirleri bahsi, Trabzonlu Aș1k Mehmed'in ömrünün sonlarında (16. yüzyıl sonu-17. yüzyıl başı) kaleme aldığ1 eseri Menâzıru'l Avâlim'de daha geniş haliyle anlatılır. Anlatıların çoğunun bizzat müellifi Trabzonlu Aşı Mehmed'in müşahedelerine dayanan eserde Tuna Nehri'nin Eflak-Boğdan sınırları, İbrail ve Isakçı beldelerinden geçerek Karadeniz'e döküldüğü zikredilir. Nehrin "amik, ariz ve azim" (derin, geniş ve büyük) olduğu özellikle vurgulanır. Tuna kollarından Morova, Sava, Drava, Tise ve Küpe bahisleri yer bulur. ${ }^{32}$ Yine Karadeniz' in Kefe itibariyle Sarı Kirman, Akkerman, Sakçı ve Nehr-i Tuna (Tuna deltası)'ya uzandığı zikredilir. ${ }^{33}$ Ayrıca eserin Feth-i Arâzî ve Bilâd-ı İklîm-i Sâbi başlığının devamında Sakçı,

30 Harita için bkz. Sipahizâde Mehmed, Evzâhü'l Mesâlik ilâ Ma'rifeti'l-Büldân ve'l-Memâlik, Süleymaniye Yazma Eserler Kütüphanesi, İsmihan Sultan: 298; Sipahizâde Mehmed, Evzâhü'l Mesâlik ilâ Ma'rifeti 'l-Büldân ve'l-Memâlik, haz. İlhami Danış, Ankara 2019, s 71.

31 Sipahizâde Mehmed, a.g.e. Haz. İlhami Danış, s. 258-259.

32 Aşık Mehmed, Menâzıru'l-Avâlim, Haz. Mahmut Ak, C: 2, Ankara 2007, s. 323-324.

33 Aşı1k Mehmed, a.g.e., C: 2, s. 183. 
Akçakirman, Tırnav yerleşimleri ayrı başlıklar halinde konu edilmektedir. ${ }^{34}$

16. yüzyıl Avrupasında kartografya ve coğrafya alanlarında kayda değer gelişmeler yaşanmıştır. Bu gelişmeler sonraki süreçte Osmanlı bilim dünyasında harita ve coğrafya alanlarında etkisini sürdürmüştür. 17. yüzyılın önemli coğrafyac1-kartograflarından Katib Çelebi, Flaman coğrafyacı kartograf Gerardus Mercator'un Atlas Minor'ü olarak bilinen eserini tercüme ederek bilgilerini literatüre kazandırmış ve yeni bir tarz üzere Mercator Projeksiyonu ekseninde çizilen haritalarını aynıyla aktarmıştır. Böylece, Avrupa usulünde haritaların Osmanlı dünyasında çizilmeye başlandığı görülür. İşte bu dönemde bahsedilen eserin Levâmi 'u'n-Nur Fî Zulmet-i Atlas Minor adıyla tercümesi esnasında Eflak-Boğdan üzerine Osmanlıca ilk detaylı harita Mercator Atlası'nda yer alan Walachia Serviya Romania Bulgaria (Harita 9) haritası referans alınarak hazırlanmıştır (Harita 10). Bu haritalar, bölge ile Osmanlı Devleti arasında yaşanan siyasi ve askeri ilişkiler göz önüne alınmadan sadece coğrafi eser neşretme gayesiyle, bilimsel kaygılarla hazırlanmış olup bizzat Katib Çelebi'nin kaleminden sadır olmuştur. $^{35}$

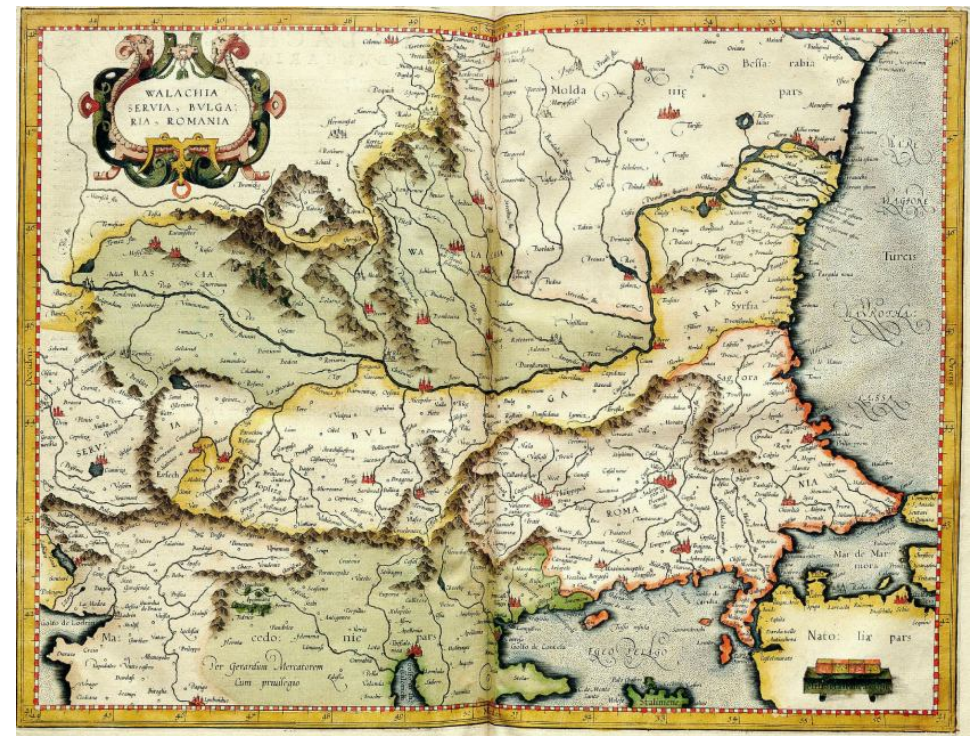

Harita-9: Walachia Serviya Romania Bulgaria Haritası, Gerardus Mercator, Jodocus Hondius, Atlas Minor Gerardi Mercatoris à I. Hondio Plurimis ceneis Tabulis Auctus Et IIllustratus, Arnheim 1621

34 Aş1k Mehmed, a.g.e., C: 3, s.1142-1143.

35 Eserin müellif hattı nüshası için bkz. Kâtib Çelebi, Levâmi 'u'n-Nûr Fî Zulmet-i Atlas Minor, Süleymaniye Yazma Eserler Kütüphanesi, Nuruosmaniye: 2998. Ayrıca bkz. Ahmet Üstüner, Levâmi'u'n-nûr (Metin-Değerlendirme), İstanbul Üniversitesi, Sosyal Bilimler Enstitüsü, Türkiyat Araştırmaları Programı, Yayımlanmamış Doktora Tezi, İstanbul 2017; Ahmet Üstüner, H. Ahmet Arslantürk, Levâmi 'u'n-Nûr Fî Zulmet-i Atlas Minor (IncelemeTipkibasım), Ankara 2017. 


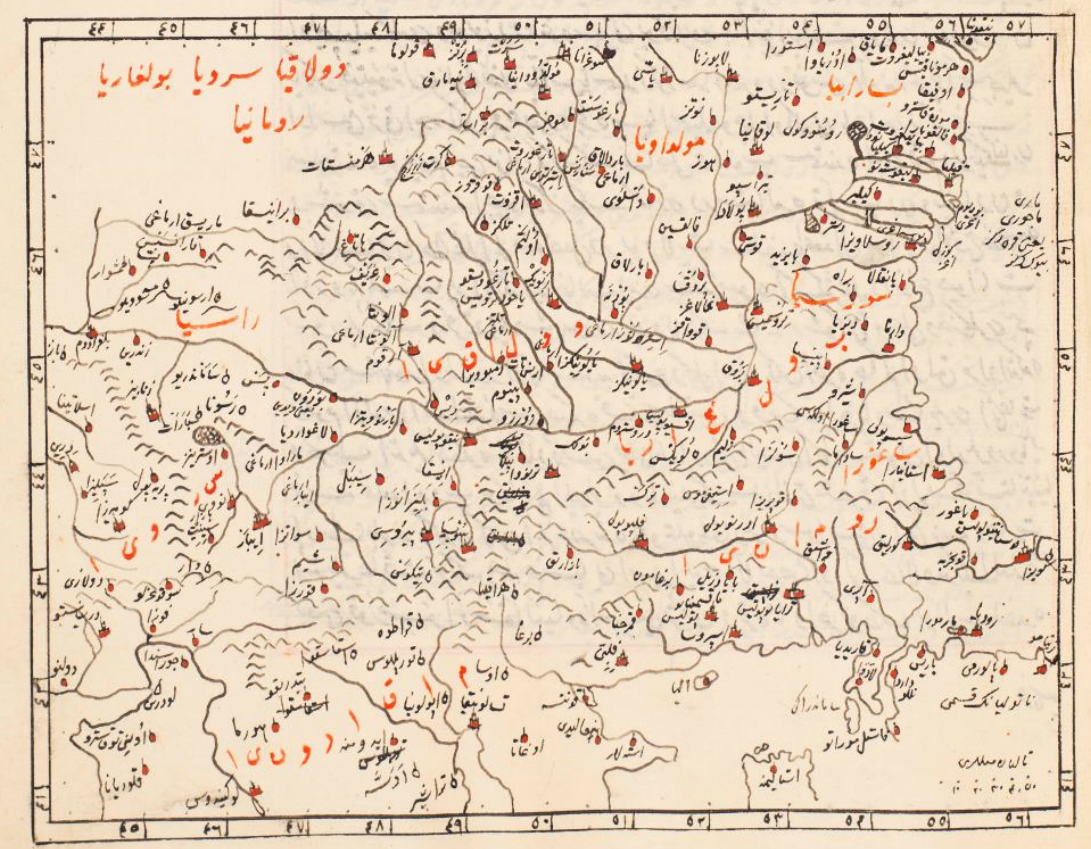

Harita-10: Valakya Serviya Bulgariya Romaniya Haritası, Kâtib Çelebi, Levâmi 'u'nNûr Fî Zulmet-i Atlas Minor, Süleymaniye Yazma Eserler Kütüphanesi, Nuruosmaniye: 2998

1653 y1lında çizilmiş olan oldukça ayrıntılı haritada kuzey yönünden itibaren kırmızı mürekkeple büyük punto ve Latince tarihsel adlandırmaya uygun olarak; Basarabya, Moldoviya, Sursiya, Valakiya, Rasiya, Bulgariya, Sagora, Serviya, Romaniya, Makadoniya bölgeleri detaylı olarak gösterilmektedir. Aynı şekilde Eflak-Boğdan'1 merkeze alan haritada önemli yerleşim yerleri Latince adlandırmaya uygun olarak gösterilmiştir. Haritanın doğu kısmında Karadeniz'in batı kıyılarından Odessa'nın güneyinden itibaren Varna ve İstanbul'a, batı kısmında ise Belgrad'a kadar uzanan bölge Tuna Nehri'nin kollarıyla birlikte gösterilmiştir. Haritada sağ alt kıyıda görüldüğü üzere Talyan Milleri (İtalya Mili) baz alınmak suretiyle çizgi ölçek kullanılmıştır. ${ }^{36}$

Haritada Mari Macori yani Karadeniz/Büyük Deniz olarak belirtilen Karadeniz'den sonra kuzeyden güneye doğru Basarabya, Moldaviya ve Valakya coğrafyasındaki isimlendirmeler genel olarak şu şekildedir: Nikoniya, Hermonaktis, Biyaligrod, Mayak, Oziyava, İstora, Lapuzna, Ayyas, Taristo, Ofika, Monkastro, Falkonara, Biyaligrot, Rosov Göli, Lukaniya, Nutz, Margosent, Kıliya, Kiliya Nova, Likosteno, Boryum Ağzı, Kiliyer, Güzel/Gözli Ağız, Posye Ağzı, Oslaviza, Dester, Pangala, Berah, Bayezid, Kuşi, Tıraspo, Huz, Polada,

36 Millerle ilgili açıklamalar için bkz. Üstüner, a.g.t. s. 39-240. 
Falkın, Bardalak Irmağı, Vasiluy, Barlak, Pudne, Senazenis, İstiretus Irmağı, Varna, Diziya, Tirosinis, Berok, Kovakz, Gallagz, Purok, İstiretus Irmağı, Teltiz(?) Irmağı, Oltem, Telkez, Akzut, Forkzoz, Kertzerberc, Alunata, Alunata Irmağ1, Arkum, Ernistat, Pinum, Ris...

Harita $44-58^{\circ}$ derece doğu boylamı ile $41-47^{\circ}$ derece kuzey enlemi içerisinde gösterilmiştir. Bugün bu değerler yaklaşık 20-30 ${ }^{\circ}$ derece doğu meridyeni ile 39-46,5 $5^{\circ}$ kuzey enlemi dahilinde yer almaktadır. 17. yüzyılda kimi zaman Kanarya Takım Adaları'nda (Cezayir-i Halidat-Fortunate Islands) bugün $18^{\circ}$ derece bat1 meridyeninde bulunan El-Hierro Adas1, kimi zaman $23^{\circ}$ derece bat1 meridyeninde bulunan Yeşil Burun (Capo Verde) kimi zaman ise $28^{\circ}$ derece bat1 meridyeninde bulunan Azor Adaları başlangıç meridyeni olarak kabul edilmektedir. $^{37}$ Mercator haritalarında boylamların Azor Adaları'ndan başladığı kabul edilirse ki haritalarda bu görülebilir, değerlerin ufak farkla 48-58 doğu meridyenine denk gelmesi beklenir. Haritada enlemlerde 2 derecelik farkla ve izdüşüm bozulmalarıyla birlikte günümüz değerlerine yakın konumlandırma yapıldığı görülmektedir. Katib Çelebi’nin söz konusu çalışmasında Osmanlı Devleti topraklarını gösteren Tursikum Imperyum başlıklı genel haritada Okzakov (Özi), Danubiyus Irmağı (Tuna), Nioster Irmağı (Özi) ve bugün Kişinev yakınlarındaki Lapusna (Lapuşna) yerleşiminin gösterildiği görülmektedir. ${ }^{38}$

Katib Çelebi'nin söz konusu tercümesi esnasında ilgili konu içerisinde bulunan bilgiler de Osmanlı bilim literatürüne dahil edilmiştir. Bu bağlamda Levami'u'n-Nur'da anlatım "Valakiya ve Serviya ve Bulgariya ve Romaniya" başlığıyla Vallakların kökenine dair bilgilerle başlar ve geniş bahisle doğal sinırlar, Prut (Yerasuz), Hoyn, Tuna Nehirleri ve Ternoviza, Brayil, Tireskortum gibi yerleşimlerden sıralanır, iklim, maişet ve madenlerden bahsedilir. ${ }^{39}$ Yine nehrin cereyan menzilinde bulunan pek çok ülkenin bahsi içerisinde Tuna Nehri zikredilir. Ayrıca Cermaniya başlığında Danubiyus yani Tuna Nehri’nden, nehrin menbaından döküldüğü yere kadar kolları, farklı coğrafyalarda ve ilkçağlardan itibaren farklı müellifler tarafından çeşitli şekillerde isimlendirilmesinden ve nehrin büyüklüğünden geniş şekilde bahsedilir. Bu bahsin bir kısmı şu şekildedir:

"Danubiyus Batlamyus ve gayriler yanında bu ismle yâd olınur lâkin Piliniyus ve Istırabo kitâbında Ister dimekle mezkûrdur Istırabo eydür. İbtidâ Denubiyus dimekle ma'rûf olup sonra Katarakta sedlere vâsıl oldukda Ister dirler ve Piliniyus eydür İlelliriyum ya'nî Bosna hudûdı ardına vâsıl oldukda ismini tebdîl ider andan Ister dirler. Batlamyus ise Aksipolis nâm şehrde ismini tebdîl ider dimişdür Apiyanus dimişdür Savus

37 Üstüner, a.g.t., s. 238-239.

38 Katib Çelebi, a.g.e., Süleymaniye Yazma Eserler Kütüphanesi, Nuruosmaniye: 2998, vr. $387 \mathrm{a}$.

39 Üstüner, a.g.t., s. 918-919. 
1rmağı ana karışduğı yirde ismini tebdîl ider. İmdi bundan ma'lûm olur ki nehr-i mezbûrun yukarısı ve Danupiyus ve aşağısı Ister dimekle müsemmâ imiş... Macinus nâm musannif Cermaniya'da dahi Pireneyi dağı vardur dimiş. Nehr-i mezbûr menba'inden çıkdukdan sonra birer sazluklara yayılup sonra bir yire gelür ve gitdükce niçe enhâr karışmağla büyür ve tavâyif-i muhtelife vilâyâtına mürûr ider. Suveviya ve Pannoniya ya'nî Macar u Bulgariya gibi ahâr altmış kadar nehr kendüye karışdukdan sonra Oksinum ya'nî Karadeniz'e dökilür Diyoniziyus ve Istırabo ve Herodotus nâm musannifler kavlince beş ağzı vardur. Piliniyus kavlince altı Ammiyanus ve Solinus kavlince yedi boğazdan dökilür. Sür'at u emvâcun kesretiyle kırk mil kadar tuzlı suya girüp karışmaz ve ol mikdâra varınca tatlu su alınur. Ammiyanus yazar ki Kara Deniz'ün en yırâk yirlerinden süri süri balıklar yavrılamak içün o cânibe teveccüh idüp nehr-i mezbûrun halâveti ile gâyet mütelezziz olurlar. Tirayanus Nerva nâm pâdişâh Niziya semtinde bu ırmak üstünde bir aceb köpri binâ itdürmiş idi sonra Adriyanus pâdişâh anı tahrîb eyledi. Neteki Diyokassus nakl u tahrîr ider ve Corciyus Faprisiyus Mesâlikü'l-memâlik kitâbında Danubiyus hakkında bu iki beyti yazmışdur: Sen ki yüz tâyifeden geçüp dünyânun büyük şehrlerini sakî itdükden sonra altı boğazla Kara Deniz'e kusarsın ve denizi basarsın." ${ }^{40}$

Klasik doğu coğrafya eserleriyle birlikte Atlas tercümesinde bulunan bu gibi bilgileri Katib Çelebi'nin farklı kurgu ve içerikle yeniden yazmaya koyulduğu Cihannüma adlı eserine kısmen dahil ettiği anlaşılmaktadır. Bu açıdan Tuna, Özi, Akkerman, Eflak ve Romanya eserde zikredilir. ${ }^{41}$ Ayrıca Katib Çelebi'nin 1656 yılında tamamlamış olduğu bir başka tarih-coğrafya eseri olan Tuhfetü'l-Kibar fi Esfâri'l-Bihar adlı çalışmasında yer alan genel haritalarda Boğdan ve Eflak bölgeleri gösterilerek özellikle Tuna Nehri, Özi, Akkerman, İsmail, Kili, Tulca, Kiligra ve İbrail'in isimlendirildiği görülmektedir (Harita 11). ${ }^{42}$ Eserin farklı istinsahlarında birbirinden farklı kalemler tarafından çizilmiş aynı coğrafyayı gösteren haritalar yer almaktadır. ${ }^{43}$

40 Üstüner, a.g.t., s. 680-681.

41 Eseri için bkz. Kâtib Çelebi, Cihannüma (II. Telif), TSMK, Revan: 1624.

42 Eserle ilgili ayrıntılar için bkz. İdris Bostan, Tuhfetü'l-Kibâr Fî Esfâri'l-Bihâr, Ankara 2018.

43 Eserin farklı nüshalarında bulunan haritalar için bkz. Katib Çelebi, Tuhfetü'l-Kibâr Fî Esfâri'l-Bihâr, Süleymaniye Yazma Eserler Kütüphanesi, Lala İsmail: 310; Hacı Beşir Ağa: 463; Revan: 1192; Mihrişah Sultan: 304; TSMK, Revan: 1195; TSMK, Y-67; İstanbul Üniversitesi Nadir Eserler Kütüphanesi (IÜNEK), TY: 6091. 


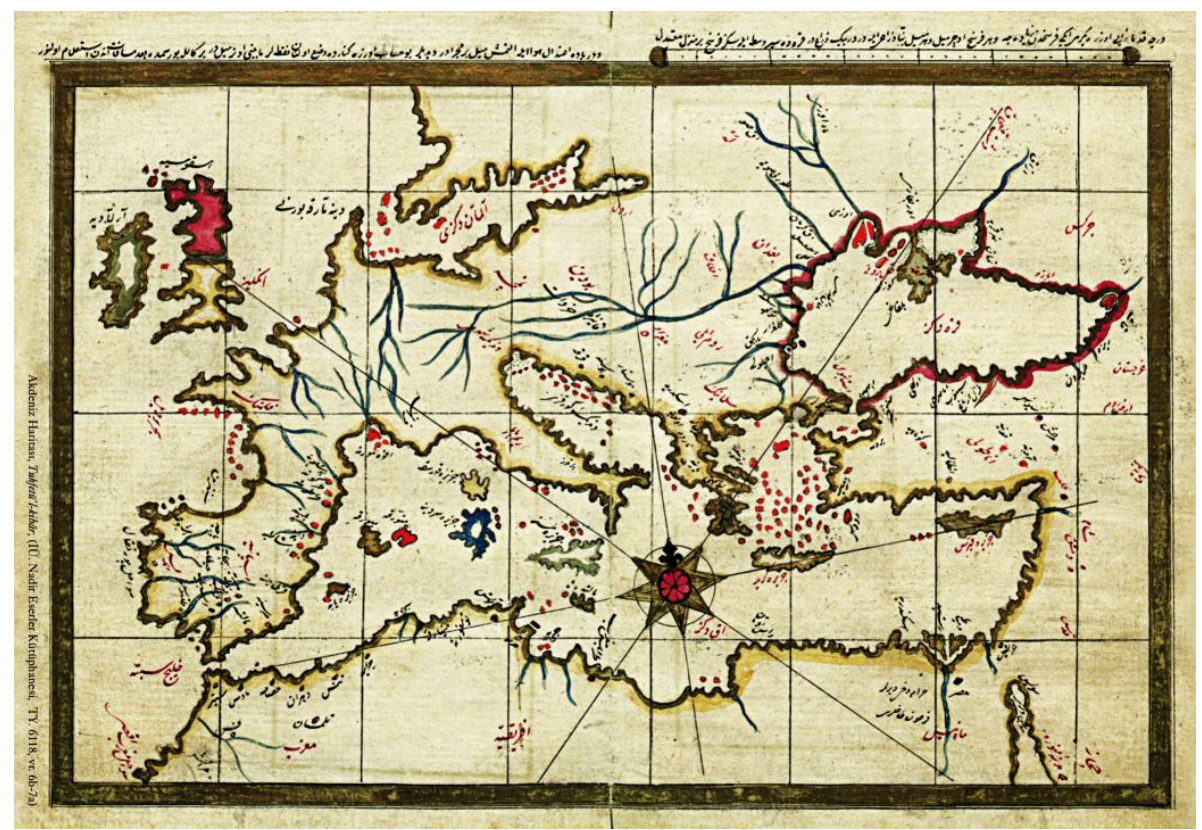

Harita-11: Sûret-i Memâlik-i Mahrûse ve Frengistan / Avrupa, Anadolu ve Kuzey Afrika Haritası, Katib Çelebi, Tuhfetü'l-Kibâr Fî Esfâri'l-Bihâr, İ̈NEK, TY: 6118 (İstinsah tarihi 1701)

17. yüzyılın ikinci yarısında diğer bir Osmanlı coğrafyacısı Ebubekir Dımeşki Avrupa'dan tercüme geleneğini sürdürmüş ve 1675-1685 yıllarında Blaeu ailesinin 1662 yılında basımını yaptığı Latince 11 ciltlik Atlas Mayor'u tercüme etmiştir. $\mathrm{Bu}$ vesile ile eserde, Eflak-Boğdan üzerine çizilmiş birtakım genel ve özel haritalar Osmanlı bilim dünyasına aktarılmışırı. Bölgeyi ayrıntılı olarak gösteren bu haritaların Eflak-Boğdan, Karadeniz, Tuna ve Özi haritaları olarak bir kaç farklı tarzda ve eserin farklı tarihli istinsah nüshalarında tekrar tekrar çizildiği dikkat çeker. ${ }^{44}$ Nusretü'l-İslam ve's-Sürûr fi Tahrîr-i Atlas Mayor ismini verdiği eserin tercüme edildiği tarihlerde vuku bulan siyasi-askeri hadiseler (Osmanl1-Lehistan savaşları, 1672-1676) ve Osmanlı Rus Savaşları (Moskof Seferi, 1676-1681) nedeniyle olsa gerektir ki Ebubekir Efendi bölgeye verdiği önemi gösterircesine bahsi geçen haritaları tekrarlamış, ayrıca Özi (Dinyeper) Nehri ve çevresini gösteren, birbirini tamamlayan iki haritayı da özenle eserine dahil etmiştir. ${ }^{45}$ Ayrıca kaynaklarda Ebubekir Dımeşki'ye ait Eflak, Boğdan, Basarabya ve Kırım bölgelerine dair bir müstakil çalışmanın

44 Örnek olarak bkz. Ebubekir b. Behram ed-Dımeşki, Muhtasar-ı Atlas Mayor, Süleymaniye Yazma Eserler Kütüphanesi, Nuruosmaniye: 2996, vr. 65; Ahmet Paşa: 173, vr. 366; TSMK, Revan: 1636, vr. 536 ve 550, Revan: 1634, vr. 349, III. Ahmet: 3095, vr. 221.

45 Ebubekir b. Behram ed-Dımeşki, Nusretü'l-İslam ve's-Sürûr fì Tahrîr-i Atlas Mayor, TSMK, Bağdat: 326, vr. 81. 
Viyana' da olduğu belirtilmektedir. ${ }^{46}$

Ebubekir Efendi'nin gerek saraya sunduğu Atlas Mayor tercümesinde gerekse eserin çeşitli muhtasar nüshalarında Latince Atlas Mayor ile birlikte Cihannüma ve portolan tarzında diğer eserlerden de yeni bilgilerle, farklı veya benzer kalemlerden çıktığı anlaşılan çizimlere rastlanmaktadır. Söz konusu çizimlerin bir kısmı bütünüyle Karadeniz ve kuzeyini göstermekte iken bazıları da münhasıran Atlas Mayor'da yer alan Walachia, Eflak-Boğdan haritasının kopyası şeklindedir (Harita 12-13). ${ }^{47}$

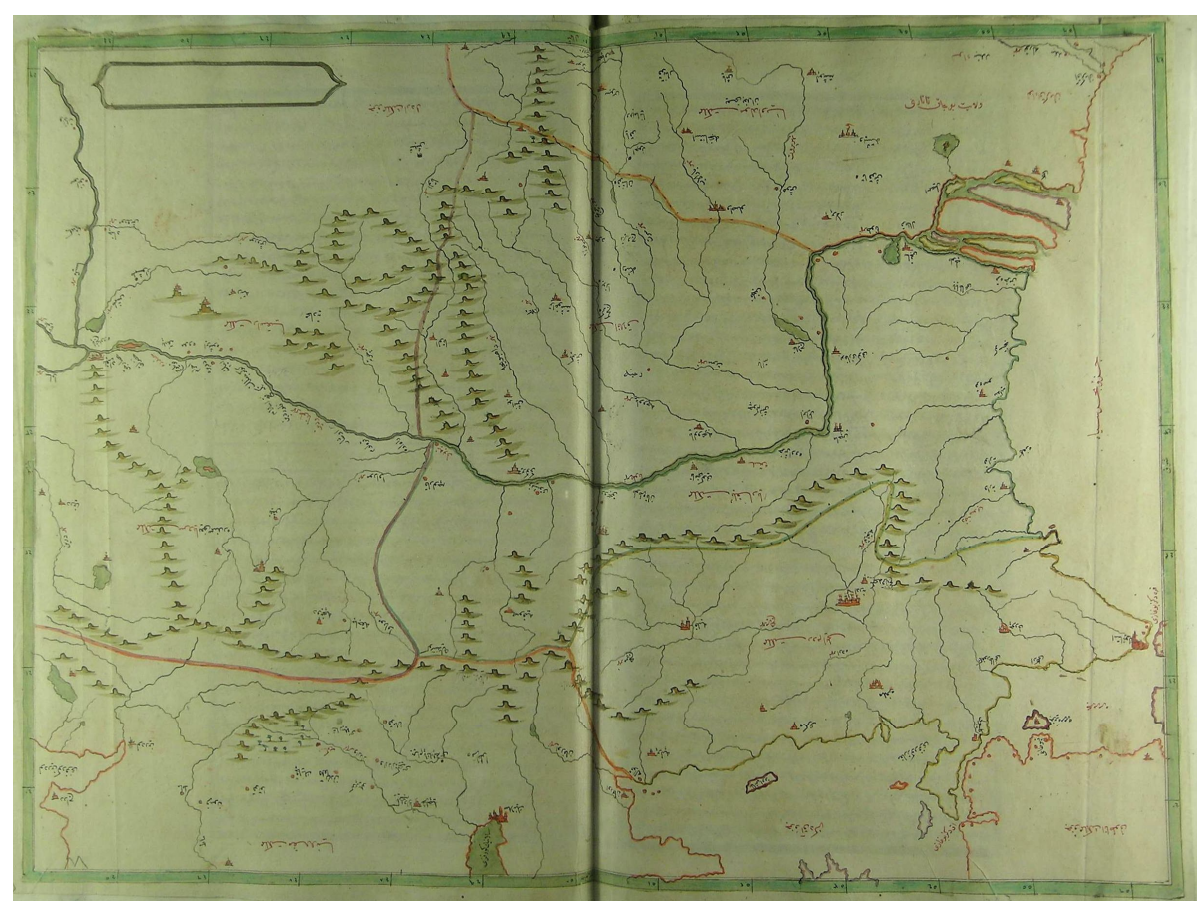

Harita-12: Eflak-Boğdan Haritası, Ebubekir b. Behram ed-Dımeşki, Muhtasar-ı Atlas Mayor, Süleymaniye Yazma Eserler Kütüphanesi, Nuruosmaniye: 2996

Harita içerik olarak Mercator haritasından intikal ettirilen mirasın hem Avrupa'da hem de Osmanlı Devleti'nde devamı niteliğinde olup Katib Çelebi'nin çizimiyle projeksiyon, içerik ve gösterilen alan açılarından benzerlik göstermektedir. Ancak enlem-boylam değerlerinde küçük farklılık görülmek-

46 Fikret Sarıcaoğlu, "Ebû Bekir b. Behrâm" DİA, C: X, İstanbul 1994, s. 110-111. Bu konuda eserin tam tercümesi olan TSMK, Bağdat: 325-333 numarada Nusretü'l-İslam ve's-Sürûr fi Tahrîr-i Atlas Mayor ismiyle kayıtlı eserde müstakil Eflak-Boğdan haritasına rastlanmamıştır. Latince aslına göre bulunması gereken yerde veya diğer ciltlerde söz konusu harita yer almamaktadır. Bu durum bahsedilen haritanın daha sonra ilgili yerden çıkarılmış olabileceğini düşündürmektedir.

47 Joan Blaeu, Atlas Maior, C: 2, Amsterdam 1662, s. 8-13. 
tedir. $44-56^{\circ}$ derece doğu boylamı ile $39-46^{\circ}$ derece kuzey enlemi değerlerinde gösterilen haritada bugünkü değerlere kıyasla $28^{\circ}$ derecelik başlangıç meridyeni farkı da dikkate alınarak enlem değerlerinin isabetine karşın boylam değerlerinde ve izdüşümde hatalar dikkat çeker. Haritalar Latince aslına mutabık olarak izdüşüm ve isimlendirme kaygısıyla yapılmış olsa da isimlendirmede Katib Çelebi haritasına nazaran detaylandırmanın daha az olduğu ve ölçek belirtilmediği görülür. İsimlerin Türkçeleştirildiği ve Latince aslından farklı yazıldığı da dikkat çeker. Ayrıca Latince haritada bulunan bir kısım yer adları dahil edilmemiştir. Kuzeyden güneye Nehr-i Turla, Nehr-i Tuna, Nehr-i Prut, Nehr-i Drava, Nehr-i Sava gibi Osmanlı iaşesi ve taşımacılık açısından önemli nehirlerin gösterilmesine özellikle dikkat edilmiş, Karadeniz kıyısı ve Tuna havzasındaki yerleşim birimleri detaylandırılmıştır. Buna göre kuzeyden güneye doğru yer alan isimlendirmeler genel olarak şu şekildedir: Akkerman, Bender, Nehr-i Turla, Livâ-i Bender, Livâ-i Akkerman, Vilâyet-i Bucak Tatarı, Lepoşte, Yaş, Kotnar, Suççar, Prut, Seret, Sibus?, Viyamaniya (Moldaviyania), Pako, Acuz, Memleket-i Moldaviya ya'nî Boğdan, İstanca, Nehr-i Baralab, Foşan, Nehr-i Prut, Hoş, Takoş, Vişte, İsmail, Kili, Vaslu, Parlad, Nehr-i Tuna, Kartal, [i]]sakcı, Tulca, Kara Harman, Baba Dağı, Falcın, Nehr-i Biziç (Bistricia), Nehr-i Siret (Strethus), Acud, Remne, Yoza, Zebruç, Memleket-i Eflak, Giyeric, Tragoşte, Nehr-i Telec, Bükreş, Nehr-i Yavoçe, Yaloviçe, Çokeniş, İbrail, Maçin, Balta, Galaç, Boğazköy, Köstence, Karasu, Silistre.

Muhtasar Atlas Mayor'ların bir başka nüshasında izdüşüm kaygısı güdülmeden sadece enlemler $40-49^{\circ}$ derece olarak belirtilmektedir. Haritada fiziki işaretlendirmelerle Karpatlar gösterilmekte, Karadeniz'in batısından itibaren Eflak-Boğdan coğrafyasına genel hatlarıla yer verilmektedir (Harita 13).

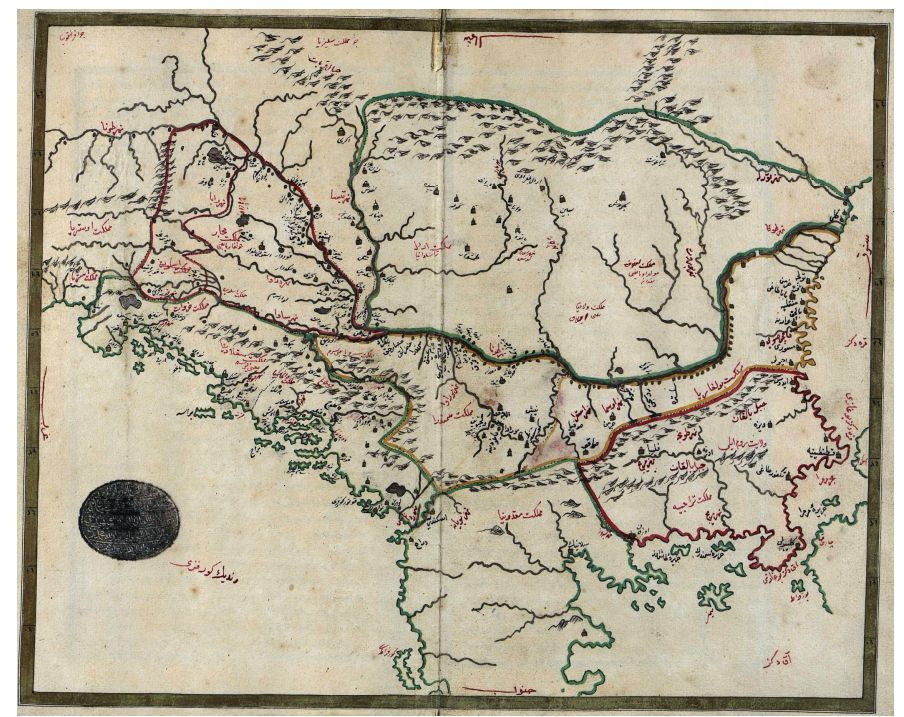

Harita-13: Eflak-Boğdan Haritası, Ebubekir b. Behram ed-Dımeşki, Muhtasar-ı Atlas Mayor, Süleymaniye Yazma Eserler Kütüphanesi, Ahmet Paşa: 173. 
Latince Atlas Mayor'da yer alan Walachia haritasının uyarlaması olan çizimde neredeyse tamamı gününün Türkçe kullanımına uygun olan isimlendirme kuzeyden güneye doğru şu şekildedir: Kili, Nehr-i Turla, Nehr-i Tuna, Tragoşte, Bukeruş, Nehr-i Prut, Memleket-i Moldaviya ya'nî Boğdan, Memleket-i Valakya ya'nî Eflak, Tulca, Kara Harman, Baba Dağı, Pankalya, Balçık, Varna, Kamçı Suyı, Silistre, Yergöği, Ruscuk, Niğbolı.

Ayrıca söz konusu nüshada bulunan benzer tarzda çizilmiş Karadeniz Haritası ayrıntı, çizim tekniği ve sanatsal çizim açılarından dikkat çekicidir. Karadeniz'in batı kıyısında Hocabeğ'den itibaren güneye doğru şu yerleşimler harita üzerinde müşahede edilmektedir (Harita 14): Hocabeğ, Nehr-i Karagâzi, Yanık Hisar, Nehr-i Turla, Akkerman, Bender, Tatar Pınarı, Bucak Tatarı, Kili, Kocagir, Kablucabalyo, İsma'̂̂l, Balban Kayası, Tağan Burnı, Kili Burnı, Tuna Boğazı, Tolçı, Karaharman, Köstence, Pankalya, Şiliye, Kavarna, Balçık, Kiligra Burnı, Galata...

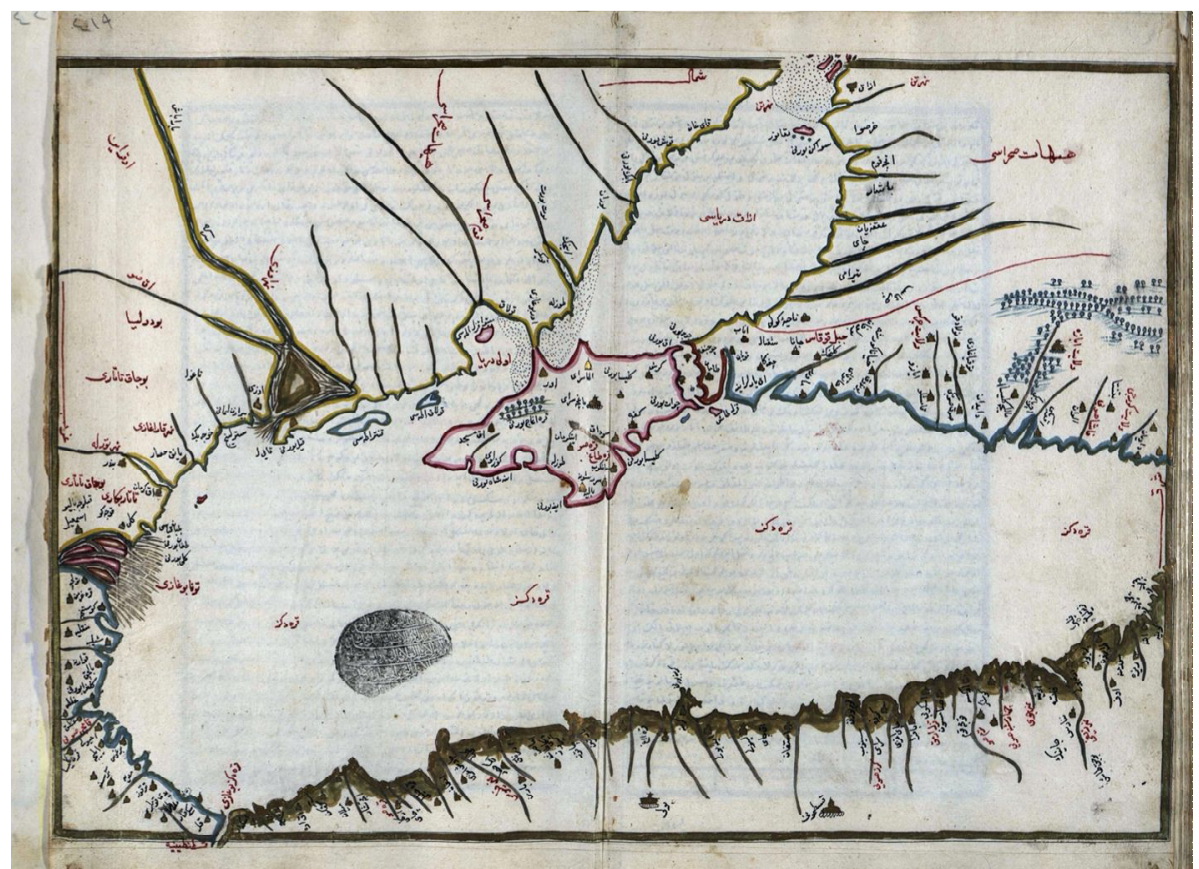

Harita-14: Karadeniz Haritası, Ebubekir b. Behram ed-Dımeşki, Muhtasar-ı Atlas Mayor, Süleymaniye Yazma Eserler Kütüphanesi, Ahmet Paşa, 173

Aynı şekilde Atlas Mayor tercümesinin saraya sunulan nüshasında yer alan Rusya/Moskov haritasında kısmen de olsa Eflak-Boğdan gösterilmiştir. Aynı çalışmada yer alan Özi çizimlerinde de Akkerman'a kadar olan kısma yer 
verildiği görülür. ${ }^{48}$ Çizimde Akkerman, Hotin, Tulça ile birlikte Tuna ve Turla Nehirleri belirtilmiştir (Harita 15).
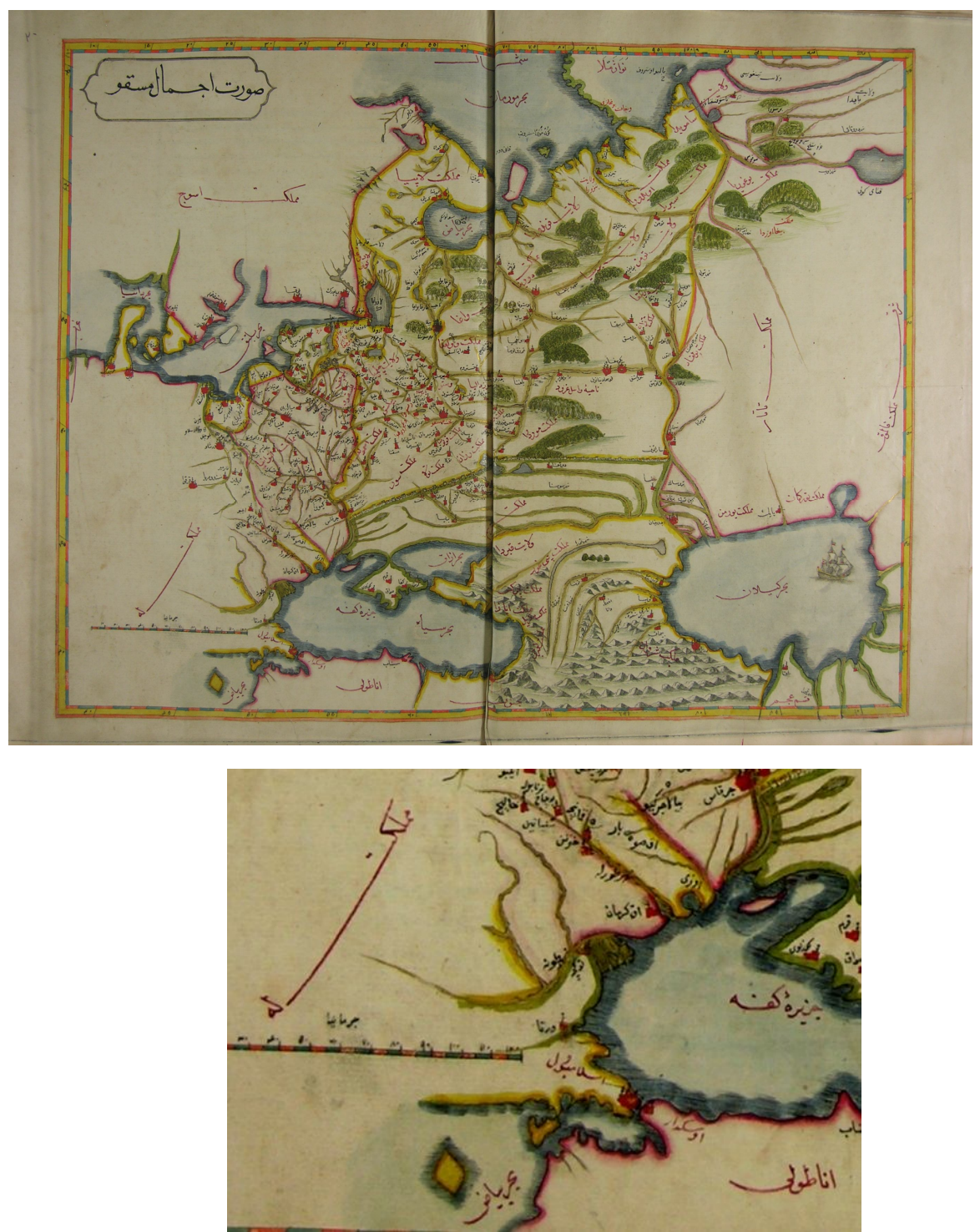

Harita-15/1, 15/2: Ebubekir b. Behram ed-Dımeșki, "Sûret-i İcmâl-i Mesko (Moskov)", Nusretü'l-İslam ve's-Sürûr Fî Tahrîr-i Atlas Mayor, TSMK, Bağdat: 326

48 Ebubekir b. Behram ed-Dımeşki, Nusretü'l-İslam ve's-Sürûr Fî Tahrîr-i Atlas Mayor, TSMK, Bağdat: 326, vr. 81-82. Ayrıca nüshada bulunmas1 gerek Eflak-Boğdan haritas1 hakkında açıklama için bkz, dipnot 46. 
Gerek Latince Atlas Mayor'da bulunan başlık ve bilgilerin aktarımı gerekse Ebubekir Efendi'nin ilave yorum ve bilgileriyle Eflak-Boğdan coğrafyası Atlas Mayor tercümelerinde serpiştirilmiş tarihi coğrafya bağlamında bilgilerle veya özgün başlıklar altında geniş yer bulur. Müstakil başlık halinde "Bâb-1 Der-beyân-1 Memleket-i Eflak ve Boğdan", "Fasl Der-beyân-1 Vilâyet-i Boğdan", "Fasl Der-beyân-1 Vilâyet-i Bucak Tatarı", "Fasl Der-beyân-1 Vilâyeti Akkerman ve Bender" başlıklarıyla Nogayların bölgeye yerleşmelerinin etkisi esere geniş ölçüde yansımış görülür. Hudud ve tarihi bilgilerle birlikte Bükreş, Kerkeç?, Poza, Recne, Sancav?, Yaş, İstanca, Hotin, Lopeşte, Akkerman, Bender gibi yerleşimler zikredilir. Coğrafya üzerinde mesafeler "merhale" ve "menzil" ifadeleriyle belirtilir. Ayrıca çeşitli sosyal ve ekonomik unsurlardan bahsedilir, yer yer enlem boylam (tûl ü arz) değerleri de verilir. ${ }^{49}$

Ebubekir Efendi'nin Atlas Tercümesi haritaları ile benzerlik gösteren müellifi ve tarihi belirlenememiş başka bir çalışma Süleymaniye Kütüphanesi, Atıf Efendi 1693 numarada kayıtlıdır. Sadece, daire-i felek, rüzgâr gülleri ve zâtül kürsi çizimleri ile birlikte 32 haritadan oluşan eserde müstakil EflakBoğdan haritası yer almaktadır (Harita 17). "Eflak Serviya ve Bulgariya ve Romanya'nın Resmidir" başlığını taşıyan söz konusu harita Atlas tercümelerinde bulunan haritalarla büyük ölçüde benzerlik göstermektedir. Haritada fiziki işaretlerle birlikte renklendirme yapılmış ve Eflak-Boğdan, Bulgariya, Rum ili coğrafyaları takribi sınırlar ile belirtilmiştir. Ayrıca eserde yer alan Avrupa (Harita 16), Karadeniz'in kuzeyi, Moskova (Resm-i İcmâlî-i Memâlik-i Moskov) ve Kırım-Azak (Resm-i İcmâlî-i Tataristan) coğrafyalarını gösteren haritalarda Eflak-Boğdan coğrafyası muhtasar olarak gösterilmektedir. ${ }^{50}$ Eser atlas tarzında olup haritalarda kullanılan çizim tekniği, başlık ve isimlendirme gibi açlara istinaden Atlas Mayor tercümelerinden istinsahla oluşturulmuş muahhar bir çalışma olduğu söylenebilir. ${ }^{51}$

49 Ebubekir b. Behram ed-Dımeşki, Muhtasar-ı Atlas Mayor, Süleymaniye Yazma Eserler Kütüphanesi, Ahmet Paşa: 173, vr. 416b-417a; Ebubekir b. Behram ed-Dımeşki, Muhtasar-l Atlas Mayor, TSMK, Revan: 1636, vr. 547a-548b.

50 Diğer haritalar için bkz. Atlas, Süleymaniye Yazma Eserler Kütüphanesi, Atıf Efendi: 1693, vr. $15 b-16 a$.

51 Haritalar Atlas Mayor tercümelerinin istinsahı kabul edilmekle birlikte çalışmada tekrara düşmemek için isimlendirmeler yazılmamıştır. 


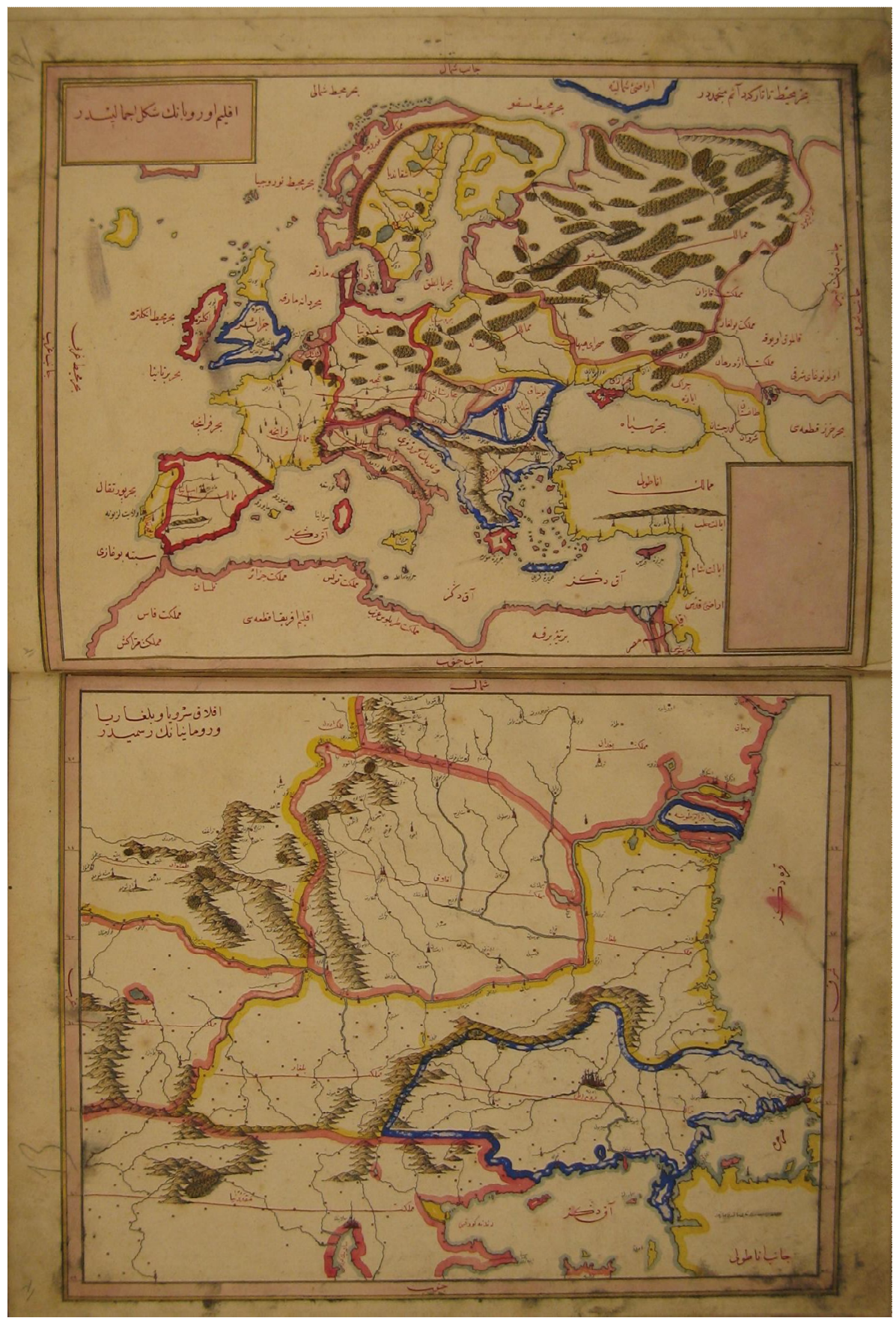

Harita-16: "Eflak Serviya ve Bulgariya ve Romanya'nın Resmidir" Harita-17: "İklîm-i Avrupa'nın Şekl-i İcmâlîsidir", Atlas, Süleymaniye Yazma Eserler Kütüphanesi, Atıf Efendi: 1693. 
17. yüzyıl öncesi coğrafya kaynaklarından Khalili Koleksiyonu'nda yer alan Atlas'ta yüzyılın sonlarında çizildiği anlaşılan Eflak-Boğdan haritası dikkat çeker. ${ }^{52}$ Genel temayülden farklı olarak önceki yüzyılın etkisiyle meydana getirilen eserde bölge ile ilgili bulunan iki haritadan birisi Kırım-Azak coğrafyası ile birlikte Özi Deltası'nı gösterirken (Harita 18/1) diğeri Karadeniz'in batı kıyıları ile birlikte Özi'den itibaren İstanbul'a kadar olan kıyı şeridini ve Tuna Deltası'nı göstermektedir (Harita 18/2). Haritalar erken dönem portolanlarının devamı niteliğinde olmakla birlikte büyük ölçüde Piri Reis'in Kitab-1 Bahriye çizimlerine dayanmaktadır. Haritalar ölçeksiz, rüzgâr gülü esasına göre çizilmiş ve gemi minyatürleriyle süslenmiştir. Sağdaki haritada kuzeyden güneye doğru isimlendirme şu şekilde devam etmektedir: Kılburun, Kal'a-i Özi, Bozo...?, Akkerman Boğazı, Yılan Adası, Kili Boğazı, Soline Boğazı, Hızır İlyas Boğazı, Borilyenilçse Boğazı?, Kara Harman Boğazı, Köstence, Pankalya, Şiliye, Kilibora, Balçık...
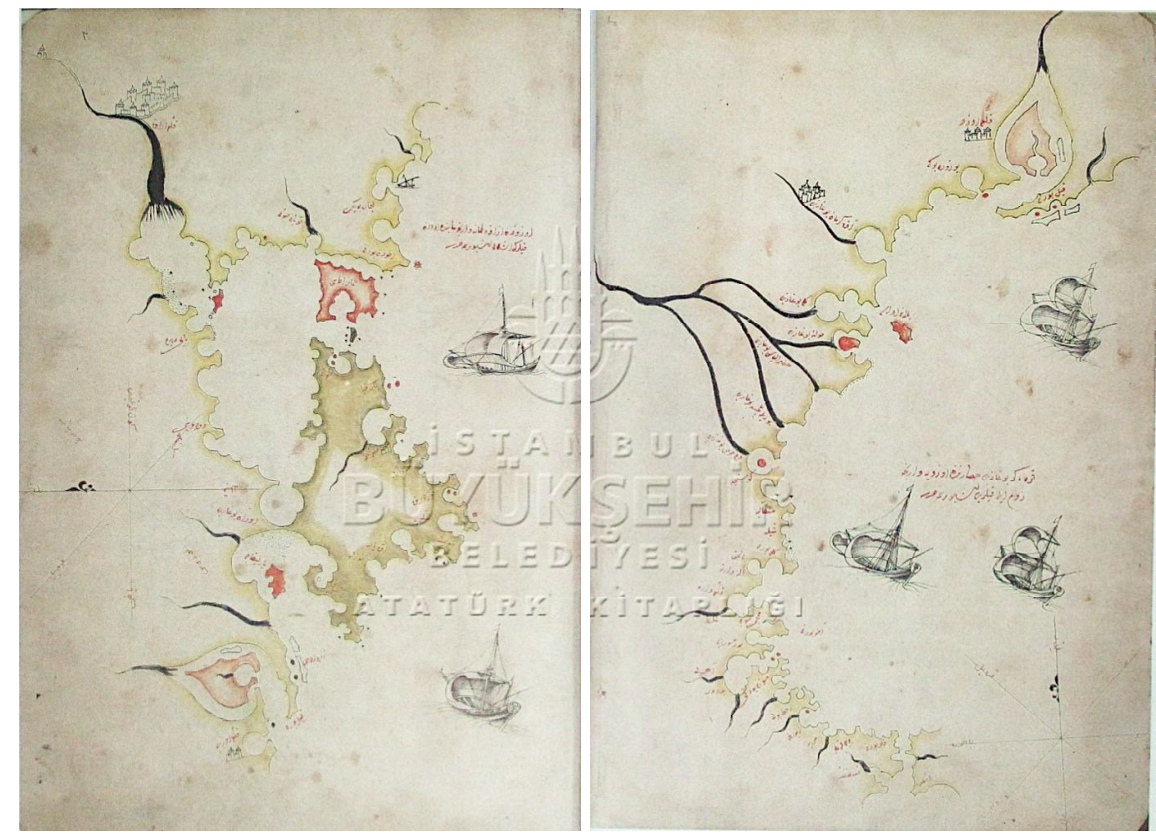

Harita-18/1-18/2: "Kırım-Azak ve Karadeniz-Tuna Deltası Haritaları”, Khalili Atlas, İstanbul Büyükşehir Belediyesi Atatürk Kitaplığı, Yaz. K-078

17. yüzyıl seyahatname ve coğrafya eseri olarak Evliya Çelebi’nin seyahatnamesi şüphesiz bölge ile ilgili geniş ve ayrıntılı anlatıma sahiptir. Bizzat gezip gördüğü coğrafyayı kendine özgü üslubuyla kaleme almıştır. Eserde bölgenin tarihine, geçmişten itibaren Osmanlıların bölgedeki mücadelelerine ve

52 Eserle ilgili ayrıntılar için ayrıca bkz. Svat Soucek, Piri Reis and Turkish Mapmaking After Columbus: The Khalili Portolan Atlas, London 1996. 
siyasi gelişmelere geniş ölçüde yer verilir.

Ayrıca gelişen siyahi hadiseler etrafinda bölgeye dair coğrafi, kültürel ve ekonomi gibi pek çok alanda özgün bilgiler aktarılır. Bu açıdan Evliya Çelebi'nin eseri, bizzat yaşadığı, şahit olduğu tarihi hadiseleri anlatmasının yanı sıra köy köy kasaba kasaba menzilleri zikretmesiyle ve coğrafya hakkında farklı açılardan bilgi vermesi yönleriyle benzersizdir. Eser, şehirler, bütünüyle yerleşimler, nehirler, kaleler, dağlar, iklim yapısı ve maişet gibi konular hakkında etraflı malumatları haizdir. ${ }^{53}$ Bu bağlamda Yılan Adası'na dair anlatım şu şekildedir:

Evsâf-1 Cezîre-i Tulça, ya 'nî Yılan Adası

şimâli ve cenûbı Nehr-i Tuna'dır. Tûlı Karadeniz’e varınca sekiz sâ'atdir. Arzı Tulça karşusundan İsmâ'îl şehri karşusuna varınca beş sâ'at yerdir, ammâ eyle hıyâbân-1 Rûm bir ormanistân ve cengelistân ve meşeyistân bir cezîredir kim içinde niçe bin gûne vahşî hayvânât ve hûş tuyûrların hisâbın cenâb-1 Bârî bilür, ammâ gücügen kuşu gâyet çokdur kim sayyâdları avlayup kanatların ok yeleği yaparlar. Ve bu cezîre içre beher sene yetmiş seksen bin sığır boğazlanup Kili pasdırması yapılan kanâre evleri vardır ve sivrisineği ol kadar çokdur kim vakt-i gurûbda âdemi ve atları helâk eder ve tatarcık sineği ve delem arısı âdemi helâk eder. İsmâ'îl ve Kili ve Tulça kal'alarında fâhişeleri dutup üryânen bu cezîreye bırağup bir gecede sivrisinek ve delem sinek ve tatarcık sinek zahmından ol avrat helâk olur.

Hulâsa-i kelâm bu cezîreyi selâmetle ubûr edüp üç günde dahi İsmâ'îl şehri önündeki Tuna-yı azîmi beş yüz pâre gemiyle geçüp ${ }^{54}$

\section{Sonuç}

Osmanlı coğrafya eserlerinin gösterdiği üzere tarihi süreç içerisinde gerek genel haritalarda gerekse özel haritalarda çeşitli sebeplerle Eflak-Boğdan haritalandırılmıştır. Bölgeye dair ilk ayrıntılı çizimler Batlamyus'tan sonra Katib Çelebi ve Ebubekir Dımeşki'nin harita uyarlamalarıdır. Bu haritalandırma işlemi haritacılık alanındaki gelişmelerin de etkisiyle zamanla ilk dönemlere nazaran daha ayrıntılı hal almıştır. 17. yüzyılda, 16. yüzyıla nazaran daha detaylı ve sayıca daha fazla Eflak-Boğdan bölgesi haritasının var olduğu görülmektedir. Ayrıca sonraki dönemlerde birtakım antlaşma, savaş, nüfus yerleşimi gibi olaylar nedeniyle de pratik anlamda bilgiler ihtiva eden çizimler de yapılmıştır.

İncelenen bütün haritalarda günümüzde de önemini koruyan şehir, kale ve nehirlerin erken dönemlerden itibaren yer bulduğu görülmektedir. Ayrıca bazı yerlerin ise önemini kaybettiği ya da haritalarda görünmediği, bazı yerlerin de isim değişikliğine uğradığı dikkat çekmektedir. Bölgedeki siyasi gücün el değiştirmesi ve tercüme eserlerden kaynaklı olarak aynı yer adı farklı şekillere

53 Evliya Çelebi, Evliya Çelebi Seyahatnamesi, C: 1-2, Haz., Seyit Ali Kahraman-Yücel Dağl1Robert Dankoff-Zekeriya Kurşun-İbrahim Sezgin, İstanbul 2011. (Özellikle, 2. ve 5. kitapta Eflak-Boğdan üzerine geniş anlatımlar vardır.)

54 Evliya Çelebi, a.g.e., C: 1, s. 5/59. 
bürünmüştür. Bu anlamda Karadeniz kıyısı ve Tuna havzasındaki şehir, kale ve nehirlerin ön plana çıktığı ve mevcudiyetini koruduğunu belirtmek gerekir. Haritalar arasında yapılacak bir kıyaslamayla Batlamyus tercümesinden itibaren isimlerin büyük ölçüde değiştiği görülür. Yine bazı yer adlarının tamamen değiştiği, bazılarının ise Kiligra-Kilibora gibi farklı telaffuzlarla yazıya geçirildiği söylenebilir. Tercüme haritalarda orijinal isimler ile birlikte Türkçe kullanımların da görüldüğü veya benzer şekilde "Giurgiu” Yergöğü, "Braila" İbrail'de olduğu gibi sesletimin Türkçeleştiği vakidir.

Katib Çelebi'nin I. Telif Cihannüma'yı yazdığg dönemden II. Telife geçiş sürecinde başta Atlas Minor olmak üzere Avrupa kaynaklarının etkisiyle EflakBoğdan coğrafyası ile ilgili bilgiler artar. II. Telif Cihannüma' da bu coğrafya ile ilgili bilgiler ziyadeleşir. Bu açıdan Atlas Minor'da Katib Çelebi'nin Avrupa'dan yapmış olduğu tercümeler, bilginin Avrupa'dan aktarımı ve Katib'in Doğu ile Batı bilgisini bir araya getirmesi bakımından (Cihanşümul kollektifi) dönüm noktasıdır. Bu üslup, sonraki süreçte de Osmanlı coğrafyacılarının takip edeceği ve gittikçe geliştireceği bir tarz olmuştur. Ebubekir Dımeşki'nin Atlas Mayor tercümesi ve Cihannüma Zeyli buna örnektir. Tarih-coğrafya bilgisinin bir arada sentezlenerek kullanılması ve pek çok açıdan detaylandırılmasıyla Evliya Çelebi’yle Eflak-Boğdan anlatımları zirveye ulaşmıştır. Bu dönemdeki haritalar bakımından Katib Çelebi teknik yaklaşım ve ayrıntılı çizimleriyle önemini korur. Ancak şunu da eklemek gerekir ki Osmanlı coğrafyacılığı ve haritacılığı 18. yüzyılda daha da ileriye taşınmış, çizilen haritalar ve bölge anlatımları gelişmiştir. Ayrıca özel amaçlara hizmet eden telif veya tercüme haritalar da vücuda getirilmiştir.

\section{KAYNAKLAR}

\section{Yazma ve Nadir Eserler}

AHMED BİN SÜLEYMAN ET-TANCI, Deniz Atlası, Topkapı Sarayı Müzesi Kütüphanesi (TSMK), Hazine: 1823.

Atlas, Süleymaniye Yazma Eserler Kütüphanesi, Atıf Efendi: 1693.

BATLAMYUS, Kitâbü'l-Coğrâfya fi'l-ma'mûre mine'l-arz, Süleymaniye Yazma Eserler Kütüphanesi, Ayasofya: 2610; 2596.

BLAEU, Joan, Atlas Maior, C: 2, Labore \&Sumptibus, Amsterdam 1662.

EBUBEKİR B. BEHRAM ED-DIMEŞKİ, Muhtasar-ı Atlas Mayor, Süleymaniye Yazma Eserler Kütüphanesi, Nuruosmaniye: 2996; Ahmet Paşa: 173; TSMK, Revan: 1636; Revan: 1634; III. Ahmet: 3095.

, Nusretü'l-İslam ve's-Sürûr fì Tahrîr-i Atlas Mayor, TSMK, Bağdat: 326. Ahmet Paşa: 173. Muhtasar-ı Atlas Mayor, Süleymaniye Yazma Eserler Kütüphanesi,

, "Sûret-i İcmâl-i Mesko (Moskov)", Nusretü'l-İslam ve's-Sürûr Fî Tahrîr-i Atlas Mayor, TSMK, Bağdat: 326.

“Eflak-Boğdan Haritası”, Ebubekir b. Behram ed-Dımeşki, Muhtasar-ı Atlas 
Mayor, Süleymaniye Yazma Eserler Kütüphanesi, Nuruosmaniye: 2996.

"Eflak Serviya ve Bulgariya ve Romanya'nın Resmidir" - “İklîm-i Avrupa'nın Şekl-i İcmâlîsidir”, Atlas, Süleymaniye Yazma Eserler Kütüphanesi, Atıf Efendi: 1693.

EL-HAC EBÜ'L-HASAN, Deniz Atlast, TSMK, Hazine: 1822.

KATİB ÇELEBİ, Cihannüma (II. Telif), TSMK, Revan: 1624.

, Levâmi 'u’n-Nûr Fî Zulmet-i Atlas Minor, Süleymaniye Yazma Eserler Kütüphanesi, Nuruosmaniye: 2998.

, Tuhfetü'l-Kibâr Fî̀ Esfâri'l-Bihâr, Süleymaniye Yazma Eserler Kütüphanesi, Lala İsmail: 310; Hacı Beşir Ağa: 463; Revan: 1192; Mihrişah Sultan: 304; TSMK, Revan: 1195; TSMK, Y-67; İ̈NNEK, TY: 6091.

“Karadeniz Haritası”, Ali Macar Reis, Ali Macar Reis Atlası, TSMK. Hazine: 644. 1621.

“Karadeniz Haritası”, Atlas-ı Hümâyûn, İstanbul Arkeoloji Müzesi Kütüphanesi:

“Karadeniz Haritası”, Walter Deniz Atlası, Walter Koleksiyonu, Baltimore.

"Kırım-Azak ve Karadeniz-Tuna Deltası Haritaları", Khalili Atlas, İstanbul Büyükşehir Belediyesi Atatürk Kitaplığı, Yaz, K-078.

La Cosmographie de Claude Ptolemée, 1411-1424.

https://commons.wikimedia.org/w/index.php?title=File:La_Cosmographie_de_ Claude_Ptolemée.pdf\&page $=4$

MERCATOR, Gerardus, Atlas Sive Cosmographicae Meditationes de Fabrica Mundi et Fabricati Fcigura, Amsterdam 1595.

Pİİ REİS, "Karadeniz ve Tuna Haritaları," Kitâb-ı Bahriyye, Walters Koleksiyonu, Baltimore.

SEYYID NUH, Kitâbu bahri'l-esved ve'l-ebyad, Bibliotheka Universiteria (Bologne) Ms. 3609.

SIPAHIZÂDE MEHMED, Evzâhü'l Mesâlik ilâ Ma'rifeti'l-Büldân ve'lMemâlik, Süleymaniye Yazma Eserler Kütüphanesi, İsmihan Sultan: 298.

"Sûret-i Memâlik-i Mahrûse ve Frengistan / Avrupa, Anadolu ve Kuzey Afrika Haritası”, Kâtib Çelebi, Tuhfetü'l-Kibâr Fî Esfâri'l-Bihâr, İÜNEK, TY: 6118. (İstinsah tarihi 1701)

"Valakya Serviya Bulgariya Romaniya Haritası", Kâtib Çelebi, Levâmi 'u’nNûr Fî Zulmet-i Atlas Minor, Süleymaniye Yazma Eserler Kütüphanesi, Nuruosmaniye: 2998.

"Walachia Serviya Romania Bulgaria Haritası", Gerardus Mercator, Jodocus Hondius, Atlas Minor Gerardi Mercatoris à I. Hondio Plurimis ceneis Tabulis Auctus Et Illustratus, Arnheim 1621.

\section{Kitap ve Makaleler}

AŞIK MEHMED, Menâzıru'l-Avâlim, haz. Mahmut Ak, TTK, Ankara 2007. 

Ss. 196-199.

AYDIN, Cengiz, AYDIN, Gülseren, "Batlamyus", DİA, C: V, İstanbul 1992,

AYGÜN, Abdurrahman, "Topkapı Sarayı Müzesindeki Coğrafi Eserler ve Haritalar”, Haritalar Mecmuast, C: IV/13, İstanbul 1933, ss.108-113.

BABINGER, Franz, "Seyyid Nuh and His Turkish Sailing Handbook." Imago Mundi C: 12, London 1955, ss. 180-82.

BOSTAN, İdris, Tuhfetü'l-Kibâr Fî Esfâri'l-Bihâr, TÜBA, Ankara 2018.

ÇİFTÇİ, Cafer, "Bâb-1 Âlî’nin Avrupa’ya Çevrilmiş İki Gözü: Eflak ve Boğdan'da Fenerli Voyvodalar (1711-1821)", Uluslararası Illişkiler, C: 7, S: 26, İstanbul 2010, ss. 27-48.

EVLIYYA ÇELEBİ, Evliya Çelebi Seyahatnamesi, C: 1-2, haz., Seyit Ali Kahraman, Yücel Dağlı, Robert Dankoff, Zekeriya Kurşun, İbrahim Sezgin, Yapıkredi Yay., İstanbul 2011.

GOODRICH, Thomas, "Atlas-1 hümayun: A Sixteenth-century Ottoman Maritime Atlas Discovered in 1984," Archivum Ottomanicum, C: 10, Budapeşte 1985, ss. $83-101$. Archivum Ottomanicum, C: 11, Budapeşte 1986, ss. 25-50.

, "The Earliest Ottoman Maritime Atlas- The Walters Deniz Atlası"

GUBOĞLU, Mihail, "Osmanlılarla Romen Ülkeleri Arasındaki İlk Devir İlişkileri (1368-1456) Hakkında Belirtmeler ve Doğrultmalar”, IX. Türk Tarih Kongresi, Bildiriler, C: II, TTK, Ankara 1988, ss. 829-843.

, "Fatih'in Stefan cel Mare Üzerine İki Boğdan Seferi 1474-1476", Belleten, C: XLVII, S: 185, Ankara 1983, ss. 139-194.

, “Kanuni Sultan Süleyman'ın Boğdan Seferi ve Zaferi”, Belleten, C: L, S: 198, Ankara 1996, ss. 728-805.

KARPAT, Kemal, “Eflak”, DIA, C: X, İstanbul 1994, ss. 466-469.

, "Bucak", DIA, C: VI, İstanbul 1992, ss. 341-343.

KISSLING, Hans J., Der See-Atlas des Sejjid Nûh, Dr. Dr. Rudolf Trofenik, München 1966.

KOŁODZIEJCZYK, Dariusz, "Hotin”, DİA, C: 18, İstanbul 1998, ss. 253-254.

KONYALI, İbrahim Hakkı, Topkapı Sarayında Deri Üzerine Yapılmış Eski Haritalar, Zaman Kitaphanesi, İstanbul 1936.

KURTOĞLU, Fevzi, Türk Süel Alanında Harita ve Kroniklere Verilen Değer ve Ali Macar Reis Atlası, Sebat Basımevi, İstanbul 1935.

MAXIM, Mihai, “Tuna-i'Amire: L'organisation financière et militaire du danube Ottoman aux XVIe et XVIIe siècles à la lumière de documents Ottomans inédits", Romano-Turcica, I içinde, ISIS, İstanbul 2003, ss. 75-82. , "Moldova", DiA, C: 30, İstanbul 2005, ss. 236-238.

MEHMED ŞEVKİ, "Memleketeyn-i Müctemiateyn: Eflak-Boğdan”, Mecmuai Fünun, C: IV, S: 35, Cemiyet-i İlmiye-i Osmaniye, İstanbul 1283, ss. 56-69.

ÖZCAN, Abdülkadir, “Boğdan”, DİA, C: VI, İstanbul 1992, ss. 269-271. 
ÖZDEMIR, Kemal, Osmanlı Deniz Haritalart: Ali Macar Reis Atlası, Avea, İstanbul 1992.

Piri Reis'ten Önce ve Sonra: Topkapı Sarayı'nda Haritalar, ed. Ahmet Menteş vd., Kültür ve Turizm Bakanlığı Yay., İstanbul 2013.

PHILLIOU, Christine M., Biography of an Empire: Governing Ottomans in an Age of Revolution, University of California Press, Berkeley Los Angles, London 2011. 2017.

PTOLEMAIOS, Klaudios, Coğrafya El Kitabl, Boyut Yayıncılık, İstanbul

RENDA, Günsel, "Resimli Haritalar ve Topkapı Sarayı Koleksiyonu” Piri Reis'ten Önce ve Sonra: Topkapı Sarayı'nda Haritalar, ed. Ahmet Menteş vd., Kültür ve Turizm Bakanlığı Yay., İstanbul 2013, ss. 40-48.

SARICAOĞLU, Fikret, "Ebû Bekir b. Behrâm” DİA, C: X, İstanbul 1994, ss. $110-111$.

, "Harita”, DIA, C: XVI., İstanbul 1997, ss. 210.

, “Piri Reis'in Dünya Haritaları ve Kitab-1 Bahriyye'si", Piri Reis'ten Önce ve Sonra Topkapı Sarayı'nda Haritalar içinde, ed. Ahmet Menteş vd., Kültür ve Turizm Bakanlığı Yay., İstanbul 2013, ss. 17-28.

SİPAHIZÂDE MEHMED, Evzâhü'l Mesâlik ilâ Ma'rifeti'l-Büldân ve'lMemâlik, haz. İlhami Danış, TÜBA, Ankara 2019.

SOUCEK, Svat, Piri Reis and Turkish Mapmaking After Columbus: The Khalili Portolan Atlas, The Nour Foundation, London 1996.

İstanbul 2013.

, Piri Reis ve Kolomb Sonrası Türk Haritacılığı, Boyut Yayıncılık,

SÖZEN, Zeynep, Fenerli Beyler, 110 Yılın Öyküsü (1711-1821), Aybay Yayıncılık, İstanbul 2000.

STEVENSON, Edward Luther, Claudius Ptolemy The Geography, Dover Publications, New York 1991.

TANRIKULU, Murat, "Portolan Haritaların Kaynağı, Genel Özellikleri ve Etkileri”, Harita Dergisi, Ankara 2017, S: 157, ss. 29-38.

UZUNÇARŞILI, İsmail Hakkı, Osmanlı Tarihi, C: II-IV, TTK, Ankara 1995.

, “On Sekizinci Asırda Buğdan'a Voyvoda Tayini”, Tarih Semineri Dergisi, C: I, Ankara 1937, ss. 32-37.

ÜSTÜNER, Ahmet, ARSLANTÜRK, H. Ahmet, Levâmi 'u'n-Nûr Fî Zulmet-i Atlas Minor (Inceleme-Tipkibasim), TÜBA, Ankara 2017.

ÜSTÜNER, Ahmet, Levâmi'u'n-nûr (Metin-Değerlendirme), İstanbul Üniversitesi, Sosyal Bilimler Enstitüsü, Türkiyat Araştırmaları Programı, Yayımlanmamış Doktora Tezi, İstanbul 2017.

YALÇINKAYA, Mehmet Alaaddin, "The Role of The Principalities of Wallachia and Moldavia on Ottoman Foreign Policy at the time of Selim III (17891807)", Codrul Cosminului, C: XXIV, S: 1, Suceava 2018, ss. 179-204. 